Prepared in cooperation with the U.S. Army Corps of Engineers and the Indiana Office of Community and Rural Affairs (OCRA)

\title{
Surface-Water and Karst Groundwater Interactions and Streamflow-Response Simulations of the Karst-Influenced Upper Lost River Watershed, Orange County, Indiana
}

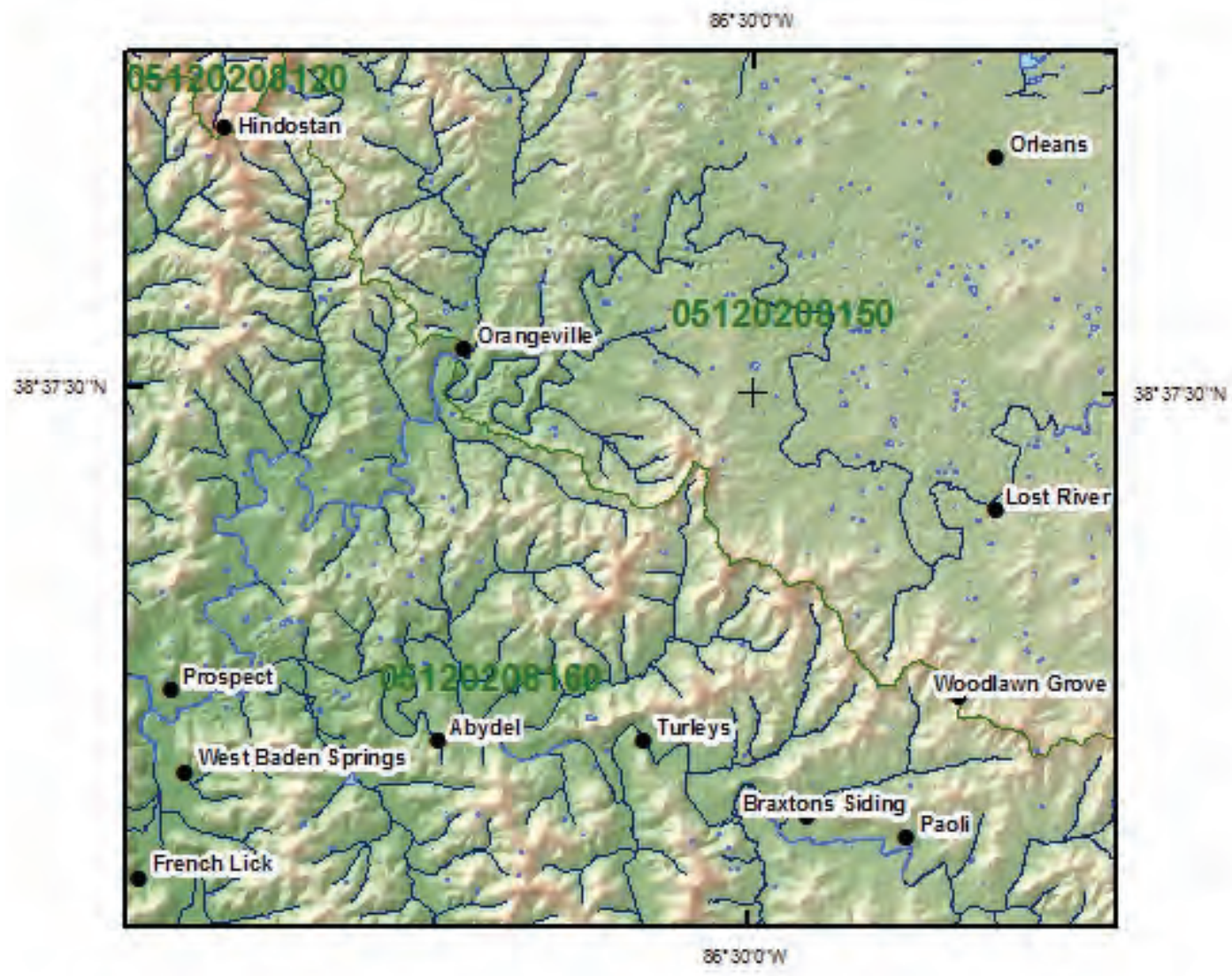

Scientific Investigations Report 2014-5028 


\section{Cover graphic:}

Portion of Lost River Basin showing boundary between the Mitchell Plain karst (upper right) and Crawford Upland (lower left). 


\section{Surface-Water and Karst Groundwater Interactions and Streamflow-Response Simulations of the Karst-Influenced Upper Lost River Watershed, Orange County, Indiana}

By E. Randall Bayless, Peter J. Cinotto, Randy L. Ulery, Charles J. Taylor, Gregory K. McCombs, Moon H. Kim, and Hugh L. Nelson Jr.

Prepared in cooperation with the U.S. Army Corps of Engineers and the Indiana Office of Community and Rural Affairs (OCRA)

Scientific Investigations Report 2014-5028 


\title{
U.S. Department of the Interior \\ SALLY JEWELL, Secretary
}

\section{U.S. Geological Survey \\ Suzette M. Kimball, Acting Director}

\author{
U.S. Geological Survey, Reston, Virginia: 2014
}

For more information on the USGS - the Federal source for science about the Earth, its natural and living resources, natural hazards, and the environment, visit http://www.usgs.gov or call 1-888-ASK-USGS.

For an overview of USGS information products, including maps, imagery, and publications, visit http://www.usgs.gov/pubprod

To order this and other USGS information products, visit http://store.usgs.gov

Any use of trade, firm, or product names is for descriptive purposes only and does not imply endorsement by the U.S. Government.

Although this information product, for the most part, is in the public domain, it also may contain copyrighted materials as noted in the text. Permission to reproduce copyrighted items must be secured from the copyright owner.

Suggested citation:

Bayless, E.R., Cinotto, P.J., Ulery, R.L., Taylor, C.J., McCombs, G.K., Kim, M.H., and Nelson Jr., H.L., 2014, Surfacewater and karst groundwater interactions and streamflow-response simulations of the karst-influenced upper Lost River watershed, Orange County, Indiana: U.S. Geological Survey Scientific Investigations Report 2014-5028, 39 p., http://dx.doi.org/10.3133/sir20145028. 


\section{Acknowledgments}

The authors thank the staff of U.S. Army Corps of Engineers (USACE) and the Indiana Office of Community and Rural Affairs (OCRA) for their assistance in conducting this study. The authors also thank the residents of Orange County, Indiana, for allowing access to their property and providing valuable insight into the local area; without this insight and assistance, this study would not have been possible. 


\section{Contents}

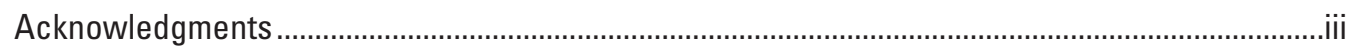

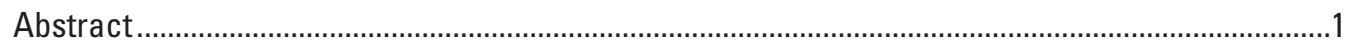

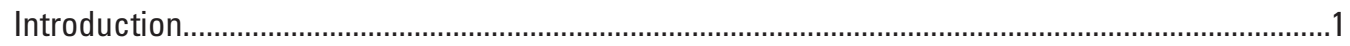

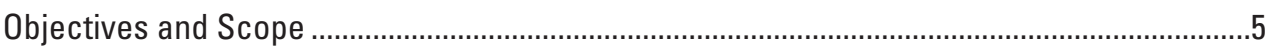

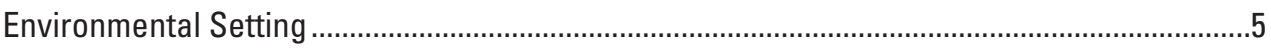

Description of Hydrologic System ....................................................................................

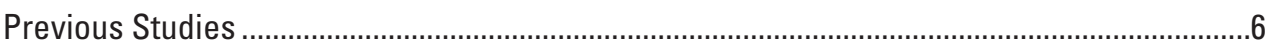

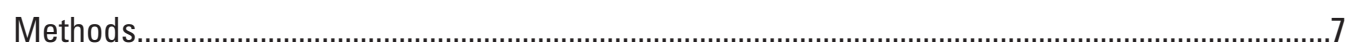

Collection and Analysis of Streamflow and Groundwater Data ............................................

Continuous Stage-Discharge Monitoring and Rating-Curve Development at Orangeville Rise and Flood Creek.......................................................................11

Event-Related Stage and Discharge Measurements ....................................................11

Observation Well and Groundwater-Level Data ..........................................................11

Application of the USGS Water Availability Tool for Environmental Resources

(WATER) Application ................................................................................................

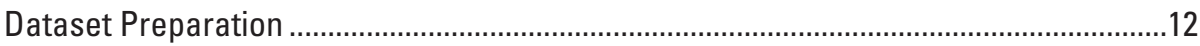

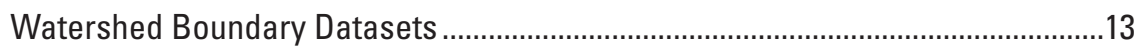

Hydrographic Datasets ..................................................................................... 13

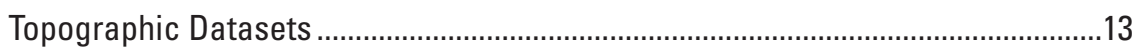

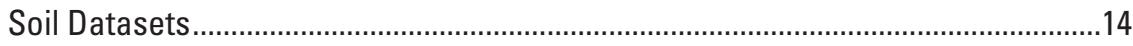

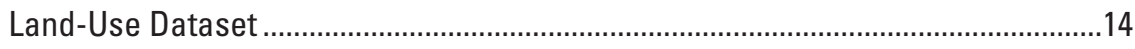

Precipitation and Temperature Datasets...........................................................14

Observed Flow Time-Series Datasets .......................................................................14

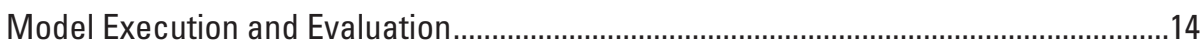

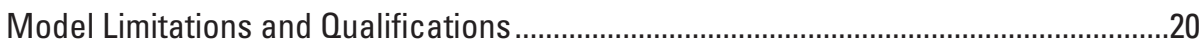

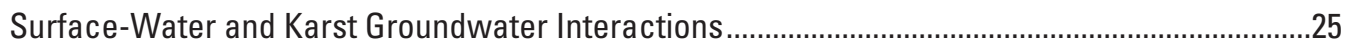

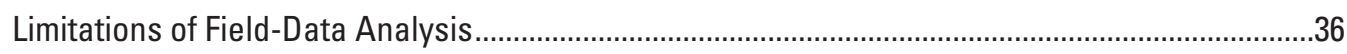

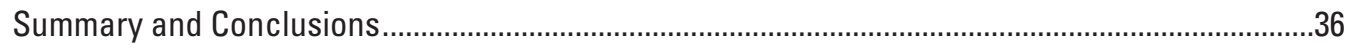

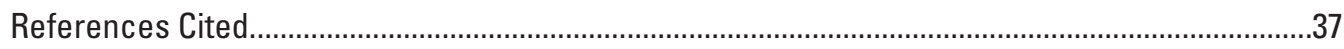

\section{Figures}

1. Regional map showing the upper Lost River watershed in Orange County, Indiana ........2

2. Photograph showing the Orangeville Rise near Orangeville, Ind. ....................................3

3. Aerial photograph showing locations of major stormwater rises in the vicinity of U.S. Geological Survey (USGS) station 03373550, Orangeville Rise near

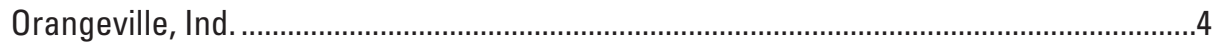

4. Photograph looking downstream at USGS streamflow-gaging station 384019086270400, Flood Creek at Orleans, Ind. 
5. Map showing data-collection sites in the upper Lost River watershed,

Orange County, Ind.

6. Map showing watersheds for three USGS streamflow-gaging stations ..........................10

7. Boxplots showing statistical distribution for simulated, optimized, and measured streamflow data for Lost River near Leipsic and Prospect watersheds, Ind., (03373530 and 03373560 , respectively).

8. Plot showing measured versus simulated hydrographs (from the USGS WATER-TOPMODEL application) for the Lost River near Leipsic, Ind. (03373530), simulation watershed.....

9. Plot showing measured versus simulated hydrographs (from the USGS WATER-TOPMODEL application) for the Lost River near Prospect, Ind. (03373560), simulation watershed.

10. Plot showing measured versus Parameter Estimation software (PEST)-optimized simulated hydrographs (from the USGS WATER-TOPMODEL application) for the Lost River near Leipsic, Ind. (03373530), simulation watershed.

11. Plot showing measured versus Parameter Estimation software (PEST)-optimized simulated hydrographs (from the USGS WATER-TOPMODEL application) for the Lost River near Prospect, Ind. (03373560), simulation watershed

12. Plot showing daily precipitation and 15-minute unit value data for USGS streamflow-gaging station 03373550 (Orangeville Rise at Orangeville, Ind.), showing double-peak nature of storm peaks and the lag time between rainfall and discharge from the spring.

13. Plot showing mean daily data for USGS streamflow-gaging station 03373550 (Orangeville Rise at Orangeville, Ind.), showing no double storm peaks owing to smoothing of the data.

14. Plot showing streamflow at Orangeville Rise at Orangeville, Ind. (03373550), and Flood Creek at Orleans, Ind. (384019086270400), and water-surface elevation in the Marshall Farm Well, Ind. (38384008601101), and Ikerd Well, Ind. (383932086281401)

15. Plot showing 15-minute unit-value water levels in the Marshall Farm Well, Ind. (383840086301101), versus 15-minute unit-value streamflow originating from the Orangeville Rise, Ind. (03373550), showing a counterclockwise hysteresis that is indicative of the groundwater peak lagging slightly behind the surface-water peak for a storm peak starting on September 7, 2012

16. Plot showing 15-minute unit-value water levels in the Marshall Farm Well, Ind. (383840086301101), versus 15-minute unit-value streamflow originating from the Orangeville Rise, Ind. (03373550), showing a counterclockwise hysteresis that is indicative of the groundwater peak lagging slightly behind the surface-water peak for a storm peak starting on September 25, 2012.

17. Plot showing 15-minute unit-value water levels in the Marshall Farm Well, Ind. (383840086301101), versus 15-minute unit-value streamflow originating from the Orangeville Rise, Ind. (03373550), showing a counterclockwise hysteresis that is indicative of the groundwater peak lagging slightly behind the surface-water peak for a storm peak starting on October 5, 2012.

18. Plot showing 15-minute unit-value water levels in the Marshall Farm Well, Ind. (383840086301101), versus 15-minute unit-value streamflow originating from the Orangeville Rise, Ind. (03373550), showing a counterclockwise hysteresis that is indicative of the groundwater peak lagging slightly behind the surface-water peak for a storm peak starting on December 8, 2012 
19. Plot showing 15-minute unit-value water levels in the Marshall Farm Well, Ind. (383840086301101), versus 15-minute unit-value streamflow originating from the Orangeville Rise, Ind. (03373550), showing an early clockwise hysteresis followed by a counterclockwise hysteresis that is indicative of an early groundwater influx followed by a more subtle rise that lags slightly behind the surface-water peak. This event started on May 4, 2012.

20. Graph showing estimated base flow, following Sloto and Crouse, for USGS streamflow-gaging station 03373550 (Orangeville Rise at Orangeville, Ind.), November 1, 2011-February 28, 2013.

21. Graph showing streamflow at Lost River near Leipsic, Ind. (03373530), Orangeville Rise near Orangeville, Ind. (03373550), and Lost River near Prospect, Ind. (03373560), streamflow-gaging stations showing a potential bounding condition at the Orangeville Rise near approximately 200 cubic feet per second

22. Graph showing streamflow at Orangeville Rise, Ind. (03373550), and water-surface elevation at Lost River at CR100E, CR500N, CR525W, and Dry Branch at CR525W showing activation of flows during periods when flows emerging from the Orangeville Rise are at, or near, approximately 200 cubic feet per second

\section{Tables}

1. List of surface-water monitoring stations in the upper Lost River watershed, Orange County, Ind.

2. List of groundwater monitoring stations in the upper Lost River watershed, Orange County, Ind. . .8

3. Simulation watersheds (with USGS station identification numbers) and respective drainage areas as used for development of the Water Availability Tool for Environmental Resources (WATER)-TOPMODEL application.

4. WATER input parameters for internally drained parts of Lost River watershed near Leipsic, Ind. (03373530), model after optimization with Parameter Estimation software (PEST) application .

5. WATER input parameters for unallocated drainage of Lost River near Leipsic, Ind. (03373530), model after optimization with PEST software application...

6. WATER input parameters for internally drained parts of Lost River watershed near Prospect Ind. (03373560), model after optimization with PEST software application

7. WATER input parameters for unallocated drainage of Lost River near Prospect, Ind. (03373560), model after optimization with PEST software application

8. Monthly results from sliding-interval, hydrograph-separation analysis (Sloto and Crouse (1996)) for station 03373550 (Orangeville Rise at Orangeville, Ind.), November 1, 2011 to February 28, 2013 


\section{Conversion Factors, Datums, and Abbreviations}

\begin{tabular}{lcl}
\hline \multicolumn{1}{c}{ Multiply } & \multicolumn{1}{c}{ By } & \multicolumn{1}{c}{ To obtain } \\
\hline inch (in.) & \multicolumn{1}{c}{ Length } & millimeter $(\mathrm{mm})$ \\
millimeter $(\mathrm{mm})$ & 0.03937 & inch (in.) \\
foot $(\mathrm{ft})$ & 0.3048 & meter $(\mathrm{m})$ \\
meter $(\mathrm{m})$ & 3.281 & foot $(\mathrm{ft})$ \\
meter $(\mathrm{m})$ & 1.094 & yard $(\mathrm{yd})$ \\
mile $(\mathrm{mi})$ & 1.609 & kilometer $(\mathrm{km})$ \\
kilometer $(\mathrm{km})$ & 0.621 & mile $(\mathrm{mi})$ \\
\hline & \multicolumn{1}{c}{ Area } & \\
\hline square mile $\left(\mathrm{mi}^{2)}\right.$ & 259.0 & hectare $(\mathrm{ha})$ \\
square mile $\left(\mathrm{mi}^{2)}\right)$ & 2.590 & square $\mathrm{kilometer}\left(\mathrm{km}^{2)}\right)$ \\
square kilometer $\left(\mathrm{km}^{2)}\right)$ & 247.1 & acre \\
square kilometer $\left(\mathrm{km}^{2)}\right)$ & 0.3861 & square mile $\left(\mathrm{mi}{ }^{2}\right)$ \\
\hline & \multicolumn{1}{c}{ Flow rate } & \\
\hline foot per day $(\mathrm{ft} / \mathrm{d})$ & 0.3048 & meter per day $(\mathrm{m} / \mathrm{d})$ \\
cubic foot per second $\left(\mathrm{ft}^{3} / \mathrm{s}\right)$ & 0.02832 & cubic meter per second $\left(\mathrm{m}^{3} / \mathrm{s}\right)$ \\
million gallons per year $(\mathrm{Mgal} / \mathrm{yr})$ & 0.00012 & cubic meter per second $\left(\mathrm{m}^{3} / \mathrm{s}\right)$ \\
inch per hour $(\mathrm{in} / \mathrm{h})$ & 0.0254 & meter per hour $(\mathrm{m} / \mathrm{h})$ \\
\hline & Hydraulic gradient & \\
\hline foot per mile $\left(\mathrm{ft} / \mathrm{mi}^{2}\right)$ & 0.1894 & meter per $\mathrm{kilometer}\left(\mathrm{m} / \mathrm{km}^{2}\right)$ \\
\hline
\end{tabular}

Temperature in degrees Fahrenheit $\left({ }^{\circ} \mathrm{F}\right)$ may be converted to degrees Celsius $\left({ }^{\circ} \mathrm{C}\right)$ as follows:

${ }^{\circ} \mathrm{C}=\left({ }^{\circ} \mathrm{F}-32\right) / 1.8$

\section{Datums}

Vertical coordinate information is referenced to the North American Vertical Datum of 1988 (NAVD 88).

Horizontal coordinate information is referenced to the North American Datum of 1983 (NAD 83).

Land-surface altitude, as used in this report, refers to distance above the vertical datum and is reported as feet above mean sea level (ft above $\mathrm{msl}$ ). 


\section{Abbreviations}

$\begin{array}{ll}\text { DEM } & \text { digital elevation model } \\ \text { Ef } & \text { Nash-Sutcliffe efficiency } \\ \text { GIS } & \text { geographic information system } \\ \text { K }_{\text {sat }} & \text { saturated hydraulic conductivity } \\ \text { NHD } & \text { National Hydrographic Dataset } \\ \text { NWIS } & \text { USGS National Water Information System } \\ \text { PEST } & \text { Parameter Estimation software } \\ \text { SDP } & \text { sinkhole-drainage process } \\ \text { SSURGO } & \text { Soil Survey Geographic database } \\ \text { TWI } & \text { topographic wetness index } \\ \text { USGS } & \text { U.S. Geological Survey } \\ \text { WATER } & \text { Water Availability Tool for Environmental Resources }\end{array}$




\title{
Surface-Water and Karst Groundwater Interactions and Streamflow-Response Simulations of the Karst-Influenced Upper Lost River Watershed, Orange County, Indiana
}

\author{
By E. Randall Bayless, ${ }^{1}$ Peter J. Cinotto, ${ }^{2}$ Randy L. Ulery, ${ }^{3}$ Charles J. Taylor, ${ }^{4}$ Gregory K. McCombs, ${ }^{2}$ \\ Moon H. Kim, ${ }^{1}$ and Hugh L. Nelson Jr. ${ }^{2}$
}

\section{Abstract}

The U.S. Geological Survey (USGS), in cooperation with the U.S. Army Corps of Engineers (USACE) and the Indiana Office of Community and Rural Affairs (OCRA), conducted a study of the upper Lost River watershed in Orange County, Indiana, from 2012 to 2013. Streamflow and groundwater data were collected at 10 data-collection sites from at least October 2012 until April 2013, and a preliminary Water Availability Tool for Environmental Resources (WATER)-TOPMODELbased hydrologic model was created to increase understanding of the complex, karstic hydraulic and hydrologic system present in the upper Lost River watershed, Orange County, Ind. Statistical assessment of the optimized hydrologic-model results were promising and returned correlation coefficients for simulated and measured stream discharge of 0.58 and 0.60 and Nash-Sutcliffe efficiency values of 0.56 and 0.39 for USGS streamflow-gaging stations 03373530 (Lost River near Leipsic, Ind.), and 03373560 (Lost River near Prospect, Ind.), respectively. Additional information to refine drainage divides is needed before applying the model to the entire karst region of south-central Indiana. Surface-water and groundwater data were used to tentatively quantify the complex hydrologic processes taking place within the watershed and provide increased understanding for future modeling and management applications. The data indicate that during wet-weather periods and after certain intense storms, the hydraulic capacity of swallow holes and subsurface conduits is overwhelmed with excess water that flows onto the surface in dry-bed relic stream channels and karst paleovalleys. Analysis of discharge data collected at USGS streamflow-gaging station 03373550 (Orangeville Rise, at Orangeville, Ind.), and other ancillary data-collection sites in the watershed, indicate that a bounding

${ }^{1}$ USGS Indiana Water Science Center, Indianapolis, Indiana.

${ }^{2}$ USGS Kentucky Water Science Center, Louisville, Kentucky.

${ }^{3}$ Retired employee of the USGS Kentucky Water Science Center, Louisville, Ky.

${ }^{4}$ Kentucky Geological Survey, Water Resources Section, Lexington, Ky. condition is likely present, and drainage from the underlying karst conduit system is potentially limited to near 200 cubic feet per second. This information will direct future studies and assist managers in understanding when the subsurface conduits may become overwhelmed.

\section{Introduction}

Flooding is a major hazard in the upper Lost River watershed in Orange County, Indiana (fig. 1). Recent major floods occurring during September 22-23, 2006, March 12-22, 2008, and June 7-9, 2008, severely impacted the townships of French Lick, West Baden Springs, and Orleans, Ind. These floods resulted in evacuation of thousands of residents; prolonged closing of roads and highways; and hundreds of millions of dollars in damage to residences, businesses, infrastructure, and agricultural lands.

The complexity of the hydrology of the karst terrain in the upper Lost River watershed makes it difficult to obtain accurate flood forecasts and design effective flood-mitigation measures. Normal dendritic streams drain much of the western and southern parts of the watershed; however, well-developed karst characterized by sinkholes, sinking streams, and underground streams or conduits dominates the watershed's drainage characteristics to the north and east. Previous dye-tracer tests have demonstrated that much of the area is drained by subsurface-karst conduits that discharge to Lost River at the Orangeville Rise near Orangeville, Ind., a large artesian karst spring located about 6 miles (mi) southwest of Orleans, Ind. (Bayless and others, 1994) (figs. 2 and 3). The methods described and applied herein are intended to provide an improved characterization of the complex hydrology in the upper Lost River watershed and to assist with solving the general problem of predicting high flows in similar karst watersheds. 


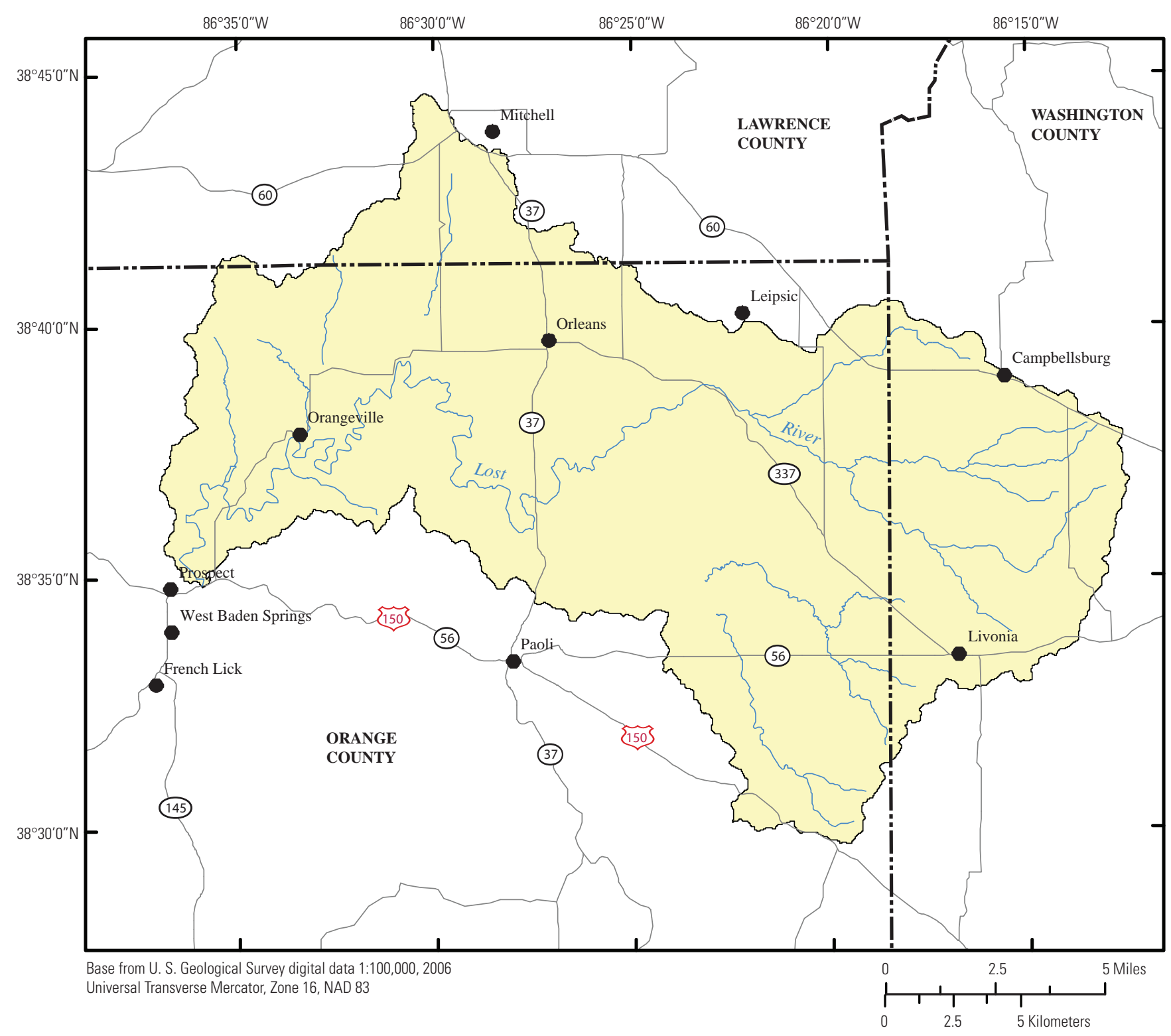

\section{EXPLANATION}

\begin{tabular}{ll}
\hline & Upper Lost River watershed boundary \\
\hline & Road \\
& Stream \\
& Town boundary
\end{tabular}

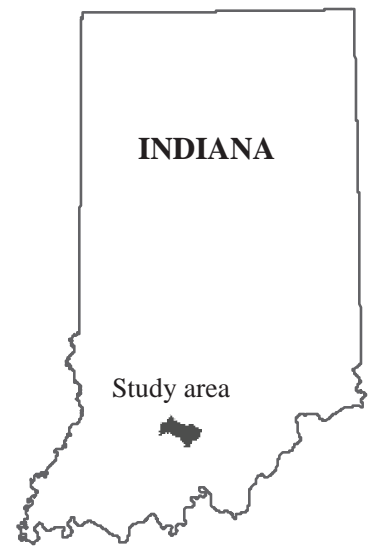

Figure 1. Regional map showing the upper Lost River watershed in Orange County, Indiana. 


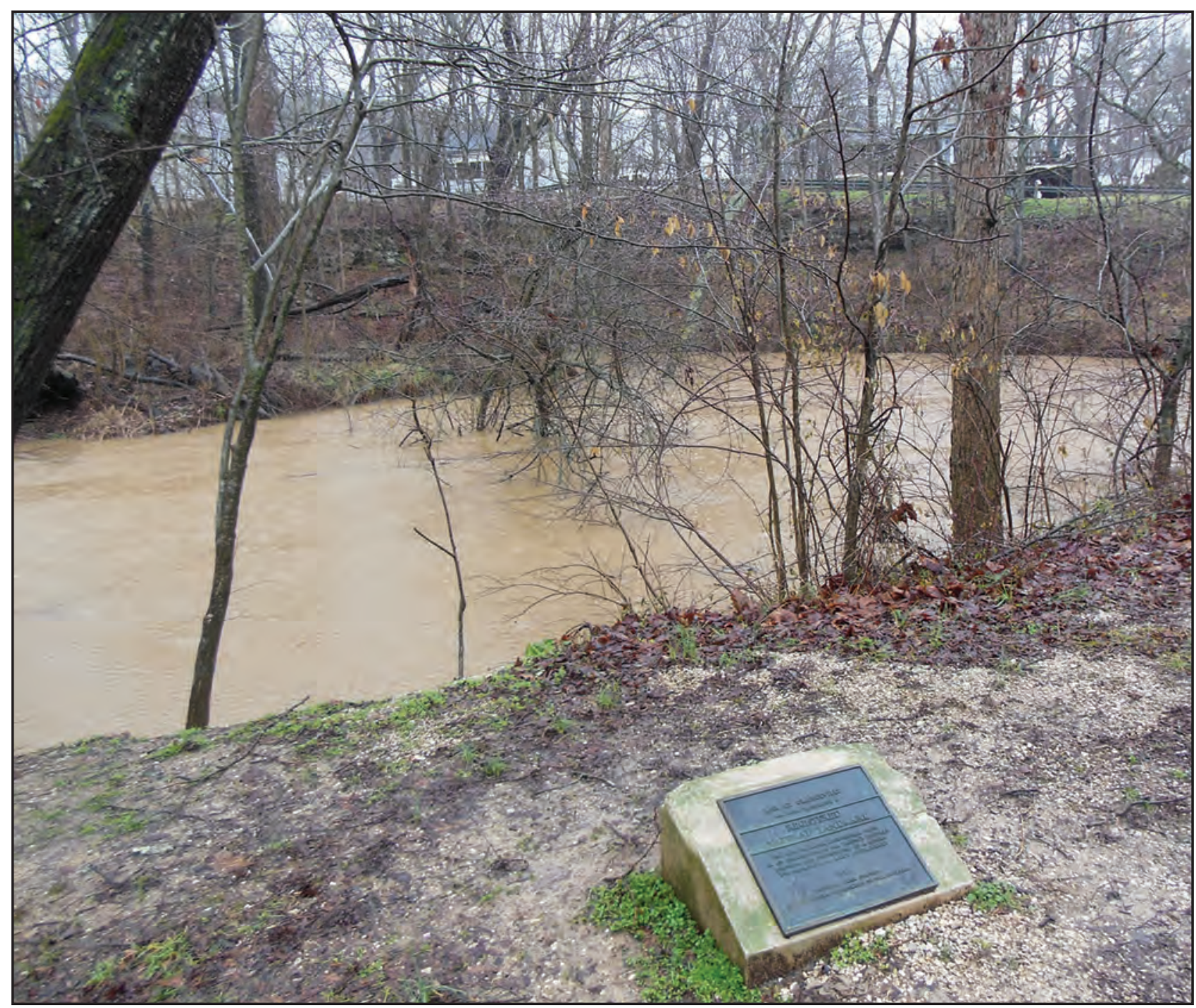

Figure 2. Orangeville Rise near Orangeville, Indiana. (Photograph taken by Ginger Korinek, Indiana Department of Natural Resources, 2011.)

One distinctive karst feature that plays a prominent role in the drainage and flooding of the watershed is the dry-bed channel of Lost River. Located between Orangeville and Leipsic, Ind., this reach of Lost River is underdrained by a large karst conduit network that discharges at the Lost River Rise, a second large artesian spring located approximately 1 mi south of the Orangeville Rise (Bassett, 1976) (fig. 3). Discharge from the Lost River Rise and Orangeville Rise combines to create the perennial headwaters for the reach of Lost River upstream of French Lick and West Baden, Ind.
Under most flow conditions, storm runoff drains from the dry bed of Lost River through a series of swallow holes, several of which are large circular depressions located adjacent to the channel. It has been observed that, during wet-weather periods, and after certain intense storms, the hydraulic capacity of these swallow holes and subsurface conduits is overwhelmed and runoff flows in the dry-bed channel. Elevated groundwater levels, that may be the result of flooding at or below Orangeville Rise and Lost River Rise, may re-activate surface flows and cause localized flooding along the dry-bed channel. 


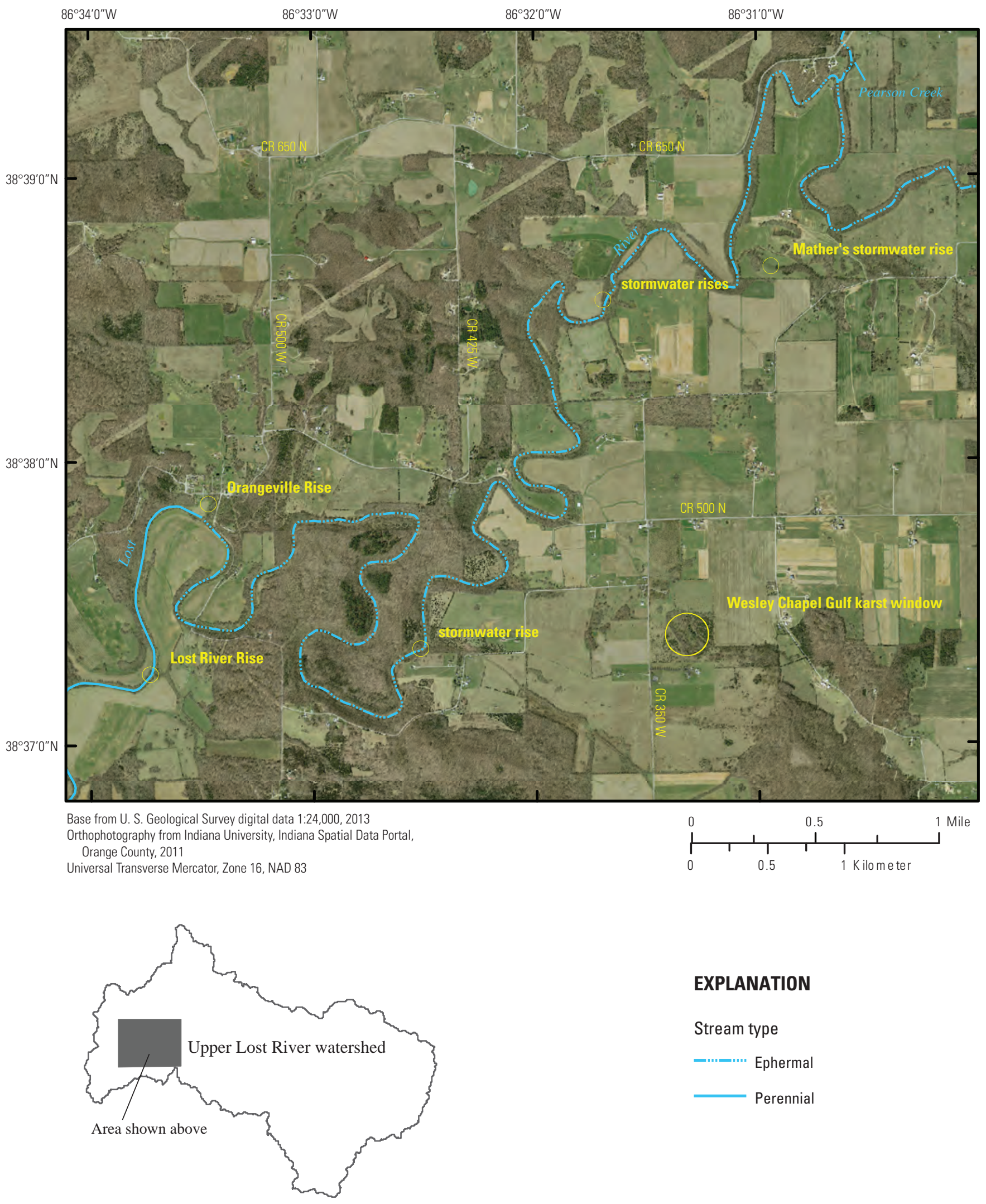

Figure 3. Aerial photograph showing locations of major stormwater rises in the vicinity of U.S. Geological Survey station 03373550, Orangeville Rise near Orangeville, Indiana. 
An additional significant hydrologic feature is Flood Creek, located in northeastern Orleans, Ind., and generally northeast of the town (fig. 4). Flood Creek drains a small (approximately 8 square miles $\left(\mathrm{mi}^{2}\right)$ ) watershed in which surface flows have been partly captured by karst conduits that discharge to the Orangeville Rise (Bayless and others, 1994). Under low-to-normal base-flow conditions, much of Flood Creek is a dry-bed stream channel and intermittent stormwater drains into the subsurface through a large swallow hole. However, when groundwater levels are elevated and (or) storm runoff exceeds the drainage capacity of the swallow hole, runoff flows over the land surface in the dry-bed channel and eventually discharges to a stormwater ditch that runs through and roughly bisects the town of Orleans. Flooding potential and frequency may be exacerbated during periods when the elevation of the groundwater table is relatively high and when discharge from Orangeville Rise is hydraulically dammed by flooding on the Lost River and (or) other mechanisms.

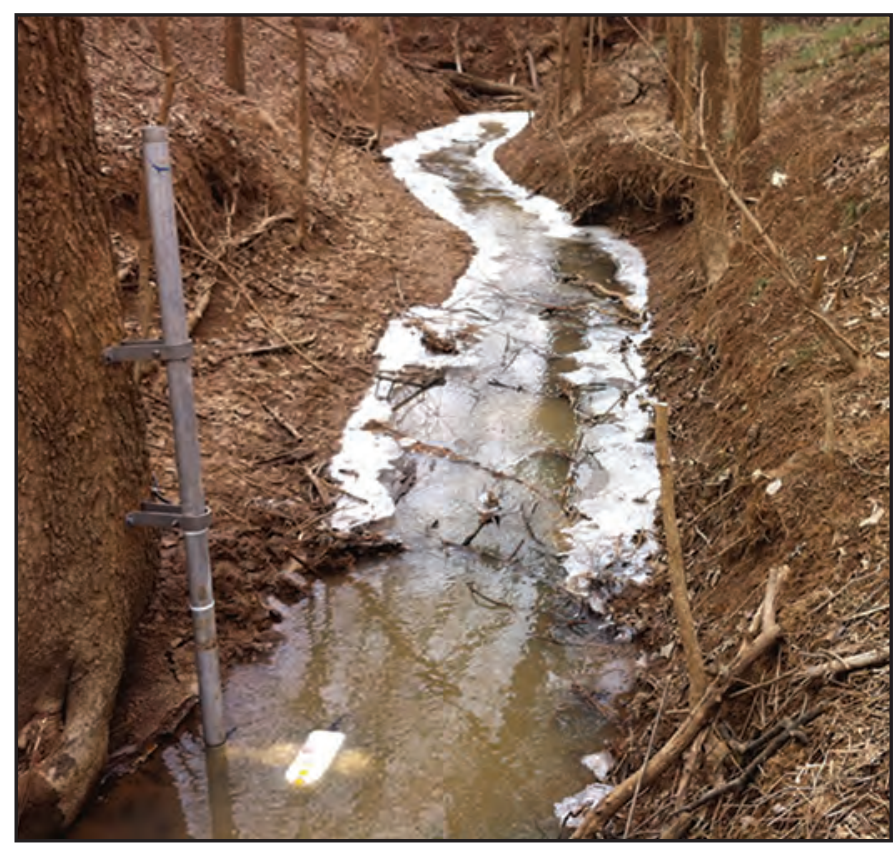

Figure 4. Looking downstream at U.S. Geological Survey streamflow-gaging station 384019086270400, Flood Creek at Orleans, Indiana. (Photograph taken by Gregory K. McCombs, U.S. Geological Survey.)

\section{Objectives and Scope}

The objectives of this report are to describe, and provide an improved understanding of, the hydrology of the upper Lost River watershed and the conditions that predicate flooding. This was partially accomplished by application of the hydrologic modeling tool-rainfall-runoff model Water Availability Tool for Environmental Resources (WATER)-TOPMODEL (Williamson and others, 2009). The WATER-TOPMODEL version used in this study included the sinkhole-drainage process (SDP) code to improve response simulations in karst drainage areas (Taylor and others, 2012).

The project objectives also were accomplished by collecting field data to describe the hydrologic responses of the system to various environmental conditions. These data included monitoring at critical locations in the upper Lost River watershed and identification of hydrologic thresholds that preclude flood events. The results produced by satisfying this objective will help emergency and water-resource managers to better understand the interaction between the karst drainage features, groundwater levels, and surface flows in the dry-bed channels of the Lost River and Flood Creek and prepare for flooding.

The data-collection network used to achieve the second objective included continuous streamflow records from eight sites and continuous groundwater levels from two wells. Long-term data for some sites in the network were available from as early as 2001. Intensive data collection for this study occurred mostly between January 2010 and February 2013. Particular emphasis for data collection was given to wetweather periods and storm events when critical high-to-floodflow (out of bank) conditions were expected to be encountered. All hydrologic data were, however, collected over a wide range of flow regimes and climatic conditions.

The spatial datasets and time-series data used to execute WATER-TOPMODEL simulations were compiled or created as described in Williamson and others (2009). These datasets were compiled from numerous sources and processed with standard geographic information system (GIS) techniques; datasets generally described watershed characteristics that would affect stream responses to rainfall events, such as topography, soils, and land use. The modeled study area encompassed $184 \mathrm{mi}^{2}$, including the upper Lost River watershed above Prospect, Ind. Subwatersheds within the larger upper Lost River watershed also were modeled and include the Lost River near Leipsic $\left(35.36 \mathrm{mi}^{2}\right)$ and Flood Creek at Orleans $\left(1.38 \mathrm{mi}^{2}\right)$.

\section{Environmental Setting}

The study area includes surface-water and groundwater watersheds above the Orangeville Rise, as well as the fringes of adjacent groundwater watersheds where groundwater divides were not previously well defined. Groundwater watersheds in the area include drainage to Sulphur Creek (northwest of West Baden, Ind.), Lost River Rise, Hamer Cave and Twin Caves (east of Mitchell, Ind.), and undetermined groundwater discharge points northwest of the study area; detailed information on these watersheds, the uncertainty regarding their contributing areas, and the larger region in general is available in Bayless and others (1994).

The study area has a humid continental climate. Weather data collected at Paoli, Ind., about $8 \mathrm{mi}$ south of Orleans, indicates that the mean annual precipitation is 47.5 inches (in.). Mean daily temperatures in January range from 18 to 38 degrees Fahrenheit $\left({ }^{\circ} \mathrm{F}\right)$ and range from 64 to $88^{\circ} \mathrm{F}$ in July (National Oceanic and Atmospheric Administration, 2013). 
The study area is within the Mitchell Plateau physiographic unit (Gray, 2000). The Mitchell Plateau is characterized by karst topography. Land surface in the Mitchell Plateau slopes to the southwest at 20 to 30 feet per mile (ft/mi) (Ruhe, 1975). Bedrock dips to the southwest at $40 \mathrm{ft} / \mathrm{mi}$. The headwaters of the Lost River are in Washington County at an altitude of about 900 feet (ft) above sea level (ASL) as referenced to the National Geodetic Vertical Datum of 1929 (Malott, 1952). Surface altitudes in the drainage watershed to Orangeville Rise range from 490 to $750 \mathrm{ft}$ ASL. Surface altitudes are about $620 \mathrm{ft}$ at Orleans and about $490 \mathrm{ft}$ at the Orangeville Rise.

The Crawford Upland physiographic unit bounds the Lost River watershed on the south and west (Schnieder, 1966). The Crawford Upland is typified by high relief and well-integrated surface drainage. The surficial geology of the Crawford Upland is composed of siliciclastic rocks of Mississippian age; these siliciclastic rocks overlie carbonate bedrock of Mississippian age that forms the Mitchell Plateau to the east. The rugged sandstone ridges that form the Crawford Upland physiographic unit are developed on sandstone deposits that are of Late Mississippian and Early Pennsylvanian age (Malott, 1952).

The Orleans area is underlain by the St. Louis Limestone and the Ste. Genevieve Limestone, which together constitute a limestone sequence that is approximately $300 \mathrm{ft}$ thick (Bassett and Ruhe, 1974). These formations consist of Mississippian-age deposits of the Blue River Group. Lower strata of the St. Louis Limestone consist mainly of pelletmicritic limestone, calcareous shale, and silty dolomite. The upper St. Louis Limestone is composed of micritic, pelletal, and skeletal limestone; some thin-bedded shale; and abundant thin beds and nodules of chert (Shaver and others, 1986). The Ste. Genevieve Limestone is composed primarily of oolitic, skeletal, micritic, and detrital limestone. The area between the headwaters of the drainage watershed and the Orangeville Rise is developed on the St. Louis Limestone, but most of the sinkhole plain is developed on the Ste. Genevieve Limestone.

Virtually all groundwater withdrawals in the study area are from bedrock aquifers. The hydraulic characteristics of limestones in the study area have been greatly altered by dissolution of soluble beds of gypsum and widening of fractures and joints. The horizontal hydraulic conductivity of non-karstic limestone generally ranges from $10^{-4}$ to $10^{-1}$ feet per day (ft/d); but in a karst area, horizontal hydraulic conductivity can range from $10^{-1}$ to $10^{3} \mathrm{ft} / \mathrm{d}$ (Freeze and Cherry, 1979). Wells completed in the St. Louis Limestone and Ste. Genevieve Limestone generally yield sufficient water to supply domestic needs but cannot sustain large, continuous withdrawals.

The St. Louis Limestone and Ste. Genevieve Limestone are mantled with 0 to $40 \mathrm{ft}$ of silt-loam soils formed in loess or bedrock residuum. These soils are silt- and clay-rich deposits that do not contain enough coarse-grained material to constitute viable aquifers.

\section{Description of Hydrologic System}

When a karst system becomes well developed, the surface- and subsurface-drainage systems are well connected. In a well-developed karst system, streams are commonly unable to flow from headwaters to mouth without periodically disappearing into sinkhole or streambed swallow holes and reemerging at other karst features farther downgradient. In such a system, water moves through the subsurface as "conduit flow" much like water flowing through a network of pipes. The discharge rate and volume of water flowing through the subsurface is related to the hydraulic gradient and the size and interconnection of the solution cavities.

The position of subsurface-drainage divides also may depend on the hydraulic gradient and the orientation of widened joints, fractures, and bedding planes in the bedrock. As a result, subsurface-drainage divides may not correspond to topographic highs or surface-drainage divides. Furthermore, karst characteristics can develop differently at various depths below the land surface; as a result, subsurface-drainage divides during high flows may not coincide with divides during low flows.

The Lost River watershed has an area with published values ranging from about $163 \mathrm{mi}^{2}$ above its confluence with Lick Creek (Murdock and Powell, 1968) to about $185 \mathrm{mi}^{2}$ (R.E. Hoggatt, U.S. Geological Survey, written commun., 1975). Most streams whose headwaters are in the eastern part of the watershed are diverted to subterranean routes when they reach the central part of the watershed because of its welldeveloped karst.

Murdock and Powell (1968) divided the Lost River watershed into six groundwater subwatersheds on the basis of hydrologic and geomorphic characteristics. Most of the study area described in this report is contained in two subwatersheds that drain to Indiana's second largest spring: the Orangeville Rise, at Orangeville, Ind. The western subwatershed drains $9.4 \mathrm{mi}^{2}$ of the Crawford Upland, and the eastern subwatershed drains $31.3 \mathrm{mi}^{2}$ of sinkhole plain. Orleans is situated in the eastern subsurface subwatershed.

\section{Previous Studies}

Previous studies of importance to this study include those of Malott (1952), Murdock and Powell (1968), Bassett (1974), Bassett and Ruhe (1974), Ruhe (1975), Bayless and others (1994), Jordan and Combs (1996), and Hasenmueller and others (2003). These studies described the local hydrology and geology, identified relic stream channels and karst paleovalleys, delineated the karst-driven groundwater divides, and began to quantify the storage potential of the underlying karst conduits.

Malott (1952) focused on the karst features of the Lost River and its intermittently dry bed. Malott described the role and relative importance of each of the swallow holes and 
springs along the river's course, including Flood Creek, the intermittent tributary that frequently floods Orleans. Malott surmised that Flood Creek, whose headwaters are about $3 \mathrm{mi}$ northeast of Orleans, once flowed within the present-day city limits on its way southwest to its confluence with the dry bed of Lost River. Malott documented flooding problems that dated to at least 1933 and attributed them to the inability of the terminal swallow hole to convey adequate amounts of storm drainage from the site. Storm drainage from Orleans likely combines with subsurface flow from the Pearson Creek drainage (Mt. Horeb Drain) and resurges at the Mather's stormwater rise.

Murdock and Powell (1968) delineated surface-water and groundwater divides in the Lost River system by means of topographic information and fluorescent dye-trace studies. Fluorescein dye was injected at low to normal flows. The 10 dye traces were used to define tentative groundwater divides between groundwater flow systems draining to the Orangeville Rise, the Rise of Lost River, Sulphur Creek, and Lick Creek; the Sulphur Creek and Lick Creek groundwater-discharge points are outside the Lost River surface-drainage system. The Orangeville Rise watershed was further divided into two subwatersheds.

Bassett (1974) did four dye-tracing tests in the Lost River watershed using rhodamine WT during relatively high flows. In three of the tests, dye was injected in the northwestern part of the drainage watershed and emerged at the Orangeville Rise. In the fourth test, dye was injected at the sink of Mosquito Creek, approximately $3.7 \mathrm{mi}$ northeast of Orleans, and emerged at Twin Caves in Spring Mill State Park. Bassett and Ruhe (1974) did quantitative dye-tracing tests from the Orleans Sewage Disposal Plant to the Orangeville Rise and measured travel times of 46 and 26 hours for moderately low and moderately high flows, respectively.

Ruhe (1975) used a hydrologic balance to estimate storage ability of the Lost River watershed. His study showed that storage was seasonally related to rates of evapotranspiration and that most of the storage capacity was in the karstic part of the watershed. Ruhe (1975) estimated that 10 to 17 percent of rainfall was discharged during summer, 79 to 86 percent was discharged during winter, and 21 to 46 percent was discharged during spring and fall. In addition, rainfall-runoff measurements by Ruhe (1975) indicated that Murdock and Powell's (1968) estimate of the area drained to the Orangeville Rise, $40.7 \mathrm{mi}^{2}$, probably is accurate.

Bayless and others (1994) used dye-tracing techniques and groundwater levels to refine the Lost River groundwaterdrainage boundary near Orleans, Ind. The study also determined that multiple factors potentially contributing to occasional flooding in Orleans include (1) the location of Orleans in a karst valley, which is overlain by low-permeability residuum that has a relatively high runoff:rainfall ratio, and (2) a limited number of sinkholes, which have been partly occluded with silt and are not capable of accepting large quantities of storm runoff. The report included an extensive, historical and partially annotated bibliography of studies with bearing on the Lost River hydrologic system, as well as a map of karst features in the watershed.

Jordan and Combs (1996) reported flooding in the Lost River watershed during 1990. Stream stage reached a peak of $27.21 \mathrm{ft}$ on May 17 at West Baden Springs, correlating to a stream discharge of 14,000 cubic feet per second $\left(\mathrm{ft}^{3} / \mathrm{s}\right)$. These were the highest stage and discharge measurements since 1964.

Hasenmueller and others (2003) describe the general karst geology, hydrology, and water quality of the Spring Mill Lake and Lost River watersheds in southern Indiana. This report includes an overview and a road log describing the karst features encountered between Indianapolis, Ind., and Spring Mill State Park near Mitchell in Lawrence County, Ind.

\section{Methods}

Data-collection methods used in the course of this study adhered to the procedures and guidelines set by the U.S. Geological Survey (USGS) unless specifically noted. Standard USGS techniques and methods, as well as quality-assurance and quality-control procedures, are set forth in numerous USGS publications; however, for groundwater data-collection activities, the USGS adhered to the methods described in Cunningham and Schalk (2011). For surface-water data-collection activities, the USGS adhered to the methods described in Sauer and Turnipseed (2010).

A range of instrumentation was used in various applications as applicable; for example, both vented and non-vented transducers were used for groundwater measurement and for short-term surface-water applications. Non-vented transducers must be corrected for atmospheric pressure when used; however, this correction was done according to manufacturer and USGS specifications to meet the accuracy requirements described in Cunningham and Schalk (2011). The same concept applies to the measurement of surface-water stage / velocity where a mixture of vented pressure transducers and one acoustic Doppler current profiler (ADCP) was used. Likewise, these units were operated according to manufacturer's specifications as well as those provided in Sauer and Turnipseed (2010).

All data were processed and preserved according to specifications outlined in Cunningham and Schalk, 2011 (groundwater); Rantz and others, 1982a and b (surface water); and numerous USGS technical memoranda devoted to newer technologies (available at http://water.usgs.gov/osw/pubs/ memo.summaries.html). Data processing included corrections for equipment drift, shifts in datum, and elimination of obvious errors. Data from real-time data-collection stations were made available through the USGS Web site within 4 hours of the parameter measurement. Non-continuous data were available within 60 days of collection through the USGS National Water Information System (NWIS) Web data portal (http:// waterdata.usgs.gov/in/nwis/). All raw and processed data were permanently archived in the USGS-managed NWIS. 


\section{Collection and Analysis of Streamflow and} Groundwater Data

A network of eight surface water and two groundwater monitoring stations was established to provide records of streamflow, stage, and groundwater levels for this analysis (tables 1 and 2). Maps showing the locations and distribution of these stations throughout the study area are provided in figures 5 and 6 .

Table 1. List of surface-water monitoring stations in the upper Lost River watershed, Orange County, Indiana.

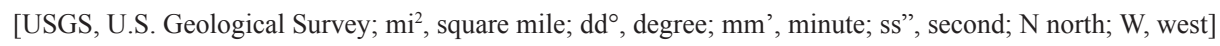

\begin{tabular}{|c|c|c|c|c|c|c|}
\hline $\begin{array}{c}\text { Site } \\
\text { number }\end{array}$ & $\begin{array}{l}\text { Project site } \\
\text { name }\end{array}$ & $\begin{array}{l}\text { USGS station } \\
\text { number }\end{array}$ & $\begin{array}{l}\text { Record } \\
\text { type }\end{array}$ & $\begin{array}{l}\text { Total drainage } \\
\text { area above site } \\
\qquad\left(\mathrm{mi}^{2}\right)^{2}\end{array}$ & $\begin{array}{l}\text { Period of } \\
\text { record used } \\
\text { for study }\end{array}$ & $\begin{array}{l}\text { Location } \\
\text { coordinates } \\
\text { (dd }{ }^{\circ} \mathrm{mm} \text { 'ss") }\end{array}$ \\
\hline 1 & $\begin{array}{l}\text { Lost River near Leipsic, } \\
\text { Indiana }\end{array}$ & 03373530 & $\begin{array}{l}\text { continuous stage- } \\
\text { discharge }\end{array}$ & 35.36 & $\begin{array}{l}1 / 1 / 2001 \text { to } \\
3 / 25 / 2013\end{array}$ & $\begin{array}{l}\text { Latitude: } 38^{\circ} 38^{\prime} 11^{\prime \prime} \mathrm{N} \\
\text { Longitude: } 86^{\circ} 211^{\prime} 55^{\prime} \mathrm{W}\end{array}$ \\
\hline 2 & $\begin{array}{l}\text { Orangeville Rise at } \\
\text { Orangeville, Indiana }\end{array}$ & 03373550 & $\begin{array}{l}\text { continuous stage- } \\
\text { discharge }\end{array}$ & 40.7 & $\begin{array}{c}10 / 14 / 2011 \text { to } \\
3 / 20 / 2013\end{array}$ & $\begin{array}{l}\text { Latitude: } 38^{\circ} 37^{\prime} 51^{\prime \prime} \mathrm{N} \\
\text { Longitude: } 86^{\circ} 33^{\prime} 26^{\prime \prime} \mathrm{W}\end{array}$ \\
\hline 3 & $\begin{array}{l}\text { Lost River near } \\
\text { Prospect, Indiana }\end{array}$ & 03373560 & $\begin{array}{l}\text { continuous stage- } \\
\text { discharge }\end{array}$ & 184.69 & $\begin{array}{r}1 / 23 / 2010 \text { to } \\
3 / 25 / 2013\end{array}$ & $\begin{array}{l}\text { Latitude: } 38^{\circ} 34^{\prime} 52^{\prime \prime} \mathrm{N} \\
\text { Longitude: } 86^{\circ} 35^{\prime} 56^{\prime \prime} \mathrm{W}\end{array}$ \\
\hline 4 & $\begin{array}{l}\text { Dry Branch at North } \\
\text { County Road } 525 \mathrm{~W} \\
\text { at Orangeville, Indiana }\end{array}$ & 383748086332200 & continuous stage & Not determined & $\begin{array}{r}4 / 25 / 2012 \text { to } \\
2 / 25 / 2013\end{array}$ & $\begin{array}{l}\text { Latitude: } 38^{\circ} 37^{\prime} 48^{\prime \prime} \mathrm{N} \\
\text { Longitude: } 86^{\circ} 33^{\prime} 22^{\prime \prime} \mathrm{W}\end{array}$ \\
\hline 6 & $\begin{array}{l}\text { Lost River at } \\
\text { West County Road } \\
\text { 500N Bridge }\end{array}$ & 383748086293300 & continuous stage & Not determined & $\begin{array}{r}4 / 25 / 2012 \text { to } \\
2 / 25 / 2013\end{array}$ & $\begin{array}{l}\text { Latitude: } 38^{\circ} 37^{\prime} 48^{\prime \prime} \mathrm{N} \\
\text { Longitude: } 86^{\circ} 29^{\prime} 33^{\prime \prime} \mathrm{W}\end{array}$ \\
\hline 7 & $\begin{array}{l}\text { Lost River at County } \\
\text { Road 100E Bridge }\end{array}$ & 383708086262000 & continuous stage & Not determined & $\begin{array}{r}4 / 25 / 2012 \text { to } \\
2 / 25 / 2013\end{array}$ & $\begin{array}{l}\text { Latitude: } 38^{\circ} 37^{\prime} 08^{\prime \prime} \mathrm{N} \\
\text { Longitude: } 86^{\circ} 26^{\prime} 20^{\prime \prime} \mathrm{W}\end{array}$ \\
\hline 8 & $\begin{array}{l}\text { Flood Creek at } \\
\text { Orleans, Indiana }\end{array}$ & 384019086270400 & $\begin{array}{l}\text { continuous stage- } \\
\text { discharge }\end{array}$ & 1.39 & $\begin{array}{r}1 / 23 / 2012 \text { to } \\
1 / 13 / 2013\end{array}$ & $\begin{array}{l}\text { Latitude: } 38^{\circ} 40^{\prime} 19^{\prime \prime} \mathrm{N} \\
\text { Longitude: } 86^{\circ} 27^{\prime} 04^{\prime \prime} \mathrm{W}\end{array}$ \\
\hline
\end{tabular}

${ }^{1}$ Sites are shown on figure 6 .

${ }^{2}$ Watershed boundaries and the resulting drainage areas were computed as described in the section titled "Watershed Boundary Datasets."

Table 2. List of groundwater monitoring stations in the upper Lost River watershed, Orange County, Indiana.

[USGS, U.S. Geological Survey; ft, foot; msl, mean sea level; $\mathrm{dd}^{\circ}$, degree; mm', minute; ss", second; W, west; N north]

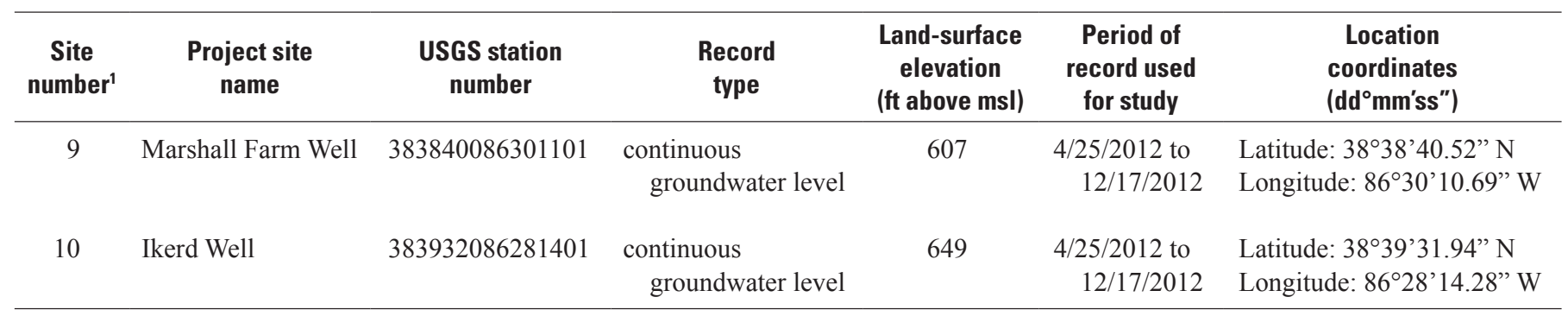

${ }^{1}$ Sites are shown on figure 6. 


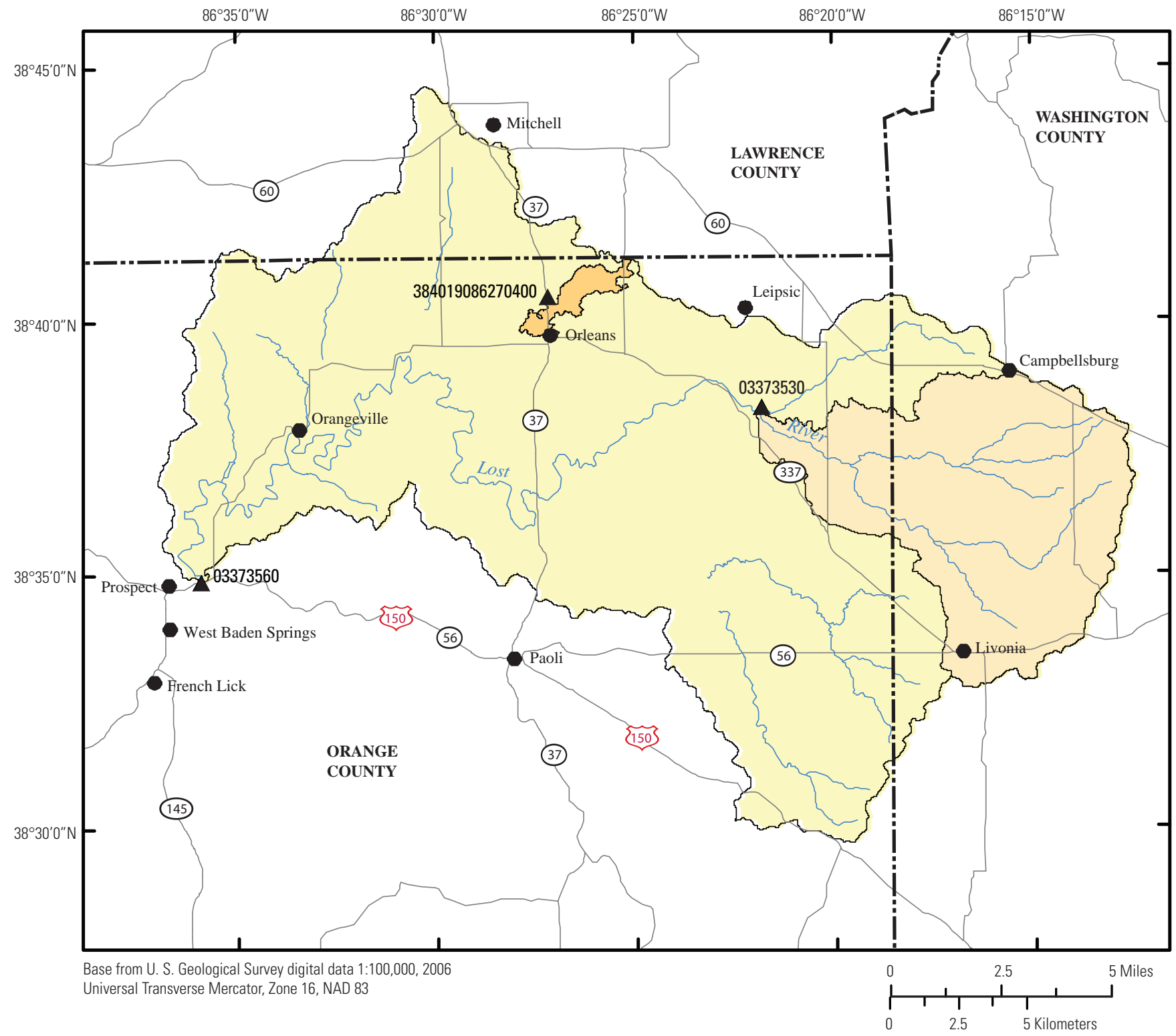

\section{EXPLANATION}

\section{Watershed boundary}

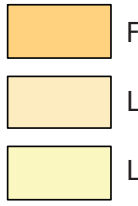

Flood Creek near Orleans

Lost River near Leipsic

Lost River near Prospect

03373560

- U.S. Geological Survey streamgage and number

Figure 5. Data-collection sites in the upper Lost River watershed, Orange County, Indiana. 


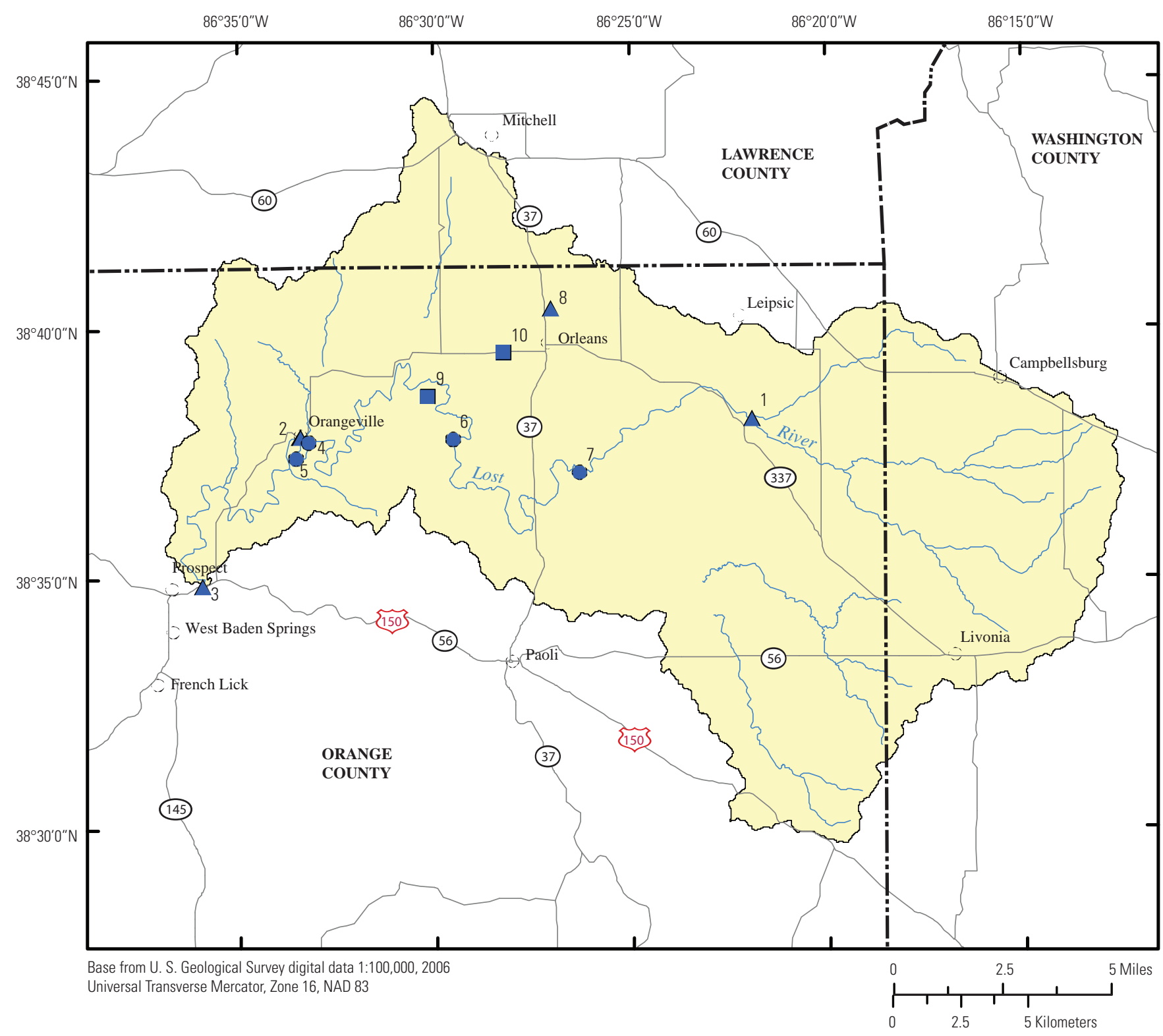

\section{EXPLANATION}

Upper Lost River watershed boundary

Monitoring stations (see tables 1 and 2 for more information)

Recorder type
$\triangle$ Continuous surface-water stage and discharge
- Continuous surface-water stage only
- Continuous groundwater level

Figure 6. Watersheds for three U.S. Geological Survey streamflow-gaging stations. 


\section{Continuous Stage-Discharge Monitoring and Rating-Curve Development at Orangeville Rise and Flood Creek}

Project-specific stage-discharge measurements for ratingcurve development were collected at Orangeville Rise at Orangeville, Ind. (Orangeville Rise), and Flood Creek at Orleans, Ind. (Flood Creek) (table 1, fig. 6), during storm events, selected high-flow periods, and routine maintenance trips to service the equipment installed at these stations. Streamflow discharge also was collected at long-term USGS streamflowgaging stations at the Lost River near Leipsic, Ind., and at Lost River near Prospect, Ind.

\section{Event-Related Stage and Discharge Measurements}

In addition to the discharge measurements being made for general rating-curve development at the Orangeville Rise and Flood Creek stations, measurements of stage and intermittent measurements of discharge in the losing (dry-bed) reach of Lost River were helpful in interpreting the hydrologic and hydraulic variables within the region and were collected, when possible, throughout the course of the study. When possible, these measurements were made during periods when water was flowing the entire length of Lost River, or at least within the main losing reach as indicated by conditions at the bridge over the Lost River at State Highway 37.

During storms, one or two two-person field teams were deployed to conduct high-flow discharge measurements at the stage-logging stations (table 1, fig. 6). Depending on conditions and availability of personnel, it was not always possible to collect synoptic measurements at all locations. For this reason, the sites were ranked for storm-discharge measurements with Flood Creek having top priority for development of a rating curve, then the automated stage-logging stations, and lastly, Orangeville Rise. Priorities were assigned based on the types of equipment at the sites and the need for site-specific data to identify localized hydrologic and hydraulic conditions of interest, such as the interaction of Flood Creek with the subsurface karst system.

\section{Observation Well and Groundwater-Level Data}

Two groundwater-observation wells were instrumented with water-level sensors and data loggers for this study: Marshall Farm Well and Ikerd Well (383840086301101 and 383932086281401 , respectively) (table 2, fig. 6). These wells are operated by using standard USGS methods described in Cunningham and Schalk (2011) and record the distance from the known surface (typically a notch on the casing) to the water surface in the well. This distance, or depth to water, is then converted to feet above mean sea level (ft above msl) by subtraction.

\section{Application of the USGS Water Availability Tool for Environmental Resources (WATER) Application}

The WATER-TOPMODEL hydrologic modeling tool (Williamson and others, 2009) was used with the SDP code (Taylor and others, 2012) to simulate streamflow responses to storms at three locations in the upper Lost River watershed. The simulated hydrographs were compared to measured data to determine the appropriateness of using this tool for flood forecasting in the upper Lost River watershed and other locations with similar karst features. In addition, the GIS datasets that were created by WATER will be available for future simulation efforts. The code was applied to watersheds with varied size and percentage of internally drained area to examine the applicability to various settings. The simulated watersheds included (1) Lost River near Leipsic, Ind. (03373530); (2) Lost River near Prospect, Ind. (03373560); and (3) Flood Creek near Orleans, Ind. (384019086270400).

The hydrologic-modeling capability of WATER is built upon the TOPMODEL rainfall-runoff approach originally developed by Beven and Kirkby (1979). The TOPMODEL approach applies the variable-source-area concept to describe how water accumulates in a simulation watershed and derives estimates of stream discharge from the frequency-distribution histogram of topographic wetness index (TWI) values computed by the equation,

$$
T W I=\ln \{A / \tan \beta\}
$$

where

$$
\begin{gathered}
\text { A is upslope contributing area per unit contour } \\
\text { width (meters) and } \\
\beta \quad \text { is local slope (degrees) as derived from a } \\
\text { preprocessed digital elevation model } \\
\text { (DEM)-based raster dataset (Quinn and } \\
\text { others, 1997). }
\end{gathered}
$$

Other critical input parameters used in the TOPMODEL approach are obtained by using climate data (precipitation and temperature) and mean soil properties obtained from the Soil Survey Geographic (SSURGO) database (http://www.soils. usda.gov/survey/geography/ssurgo/; accessed on January 15, 2009). Wolock and McCabe (1999) showed that an accurate precipitation record was the most significant variable required for a successful hydrologic-response model, while soil-moisture storage (derived from pedological data) was identified as the next most critical variable.

Williamson and others (2009) documented the creation of programming code and the input-data files used for applying the TOPMODEL application to simulate streamflow characteristics of watersheds in the non-karst areas of Kentucky. Their report provides details about the programming and input-datafile structure of the WATER-TOPMODEL code and describes procedures used in the calibration, testing, and statistical 
evaluation of TOPMODEL outputs obtained for 20 test watersheds ranging in area from 6.2 to 604 square miles $\left(\mathrm{mi}^{2}\right)$ and located throughout the State. Using SSURGO data (U.S. Department of Agriculture-Natural Resources Conservation Service, 2013 and Next Generation Weather Radar (NEXRAD) precipitation data, Williamson and others (2009) demonstrated that the WATER-TOPMODEL program developed for use in non-karst regions of Kentucky was capable of providing acceptable estimates of surface flows for a 2,119-day period of record in non-karst area watersheds, based on Nash-Sutcliffe efficiencies (Ef) ranging from 0.26 to 0.72 .

Taylor and others (2012) developed the SDP for use in the WATER-TOPMODEL application. The SDP process developed by Taylor and others (2012) incorporates three major data-processing steps beyond that used by Williamson and others (2009): (1) digitally mapped sinkholes and (or) sinking-stream catchments represented in the raster input data file are identified and delineated as internally drained subwatersheds at the beginning of WATER's simulation process; (2) the drainage (runoff, infiltration, and subsurface flow) generated from the internally drained subwatersheds is computed separately from that of the topographically drained areas of the watershed; and (3) the drainage contributed from the internally and topographically drained areas are proportionally summed to calculate a total area-weighted discharge for the simulation watershed. As part of the third step, the water-budget accounting used in the standard TOPMODEL code was modified so that the drainage into internally drained areas bypasses the base-flow coefficient in TOPMODEL and instead is computationally added directly to the stream-discharge coefficient at each time step. The practical effect of this programmed waterbudget modification is to increase the storm-peak response of simulated hydrographs, thereby better simulating the flashy hydrologic behavior typically observed for streams in conduitdominated karst regions in Kentucky. Taylor and others (2012) demonstrated that the WATER-TOPMODEL program was capable of providing acceptable estimates of surface flows in 12 karst watersheds ranging in size from 22 to $259 \mathrm{mi}^{2}$, with internally drained areas from less than 2 to about 47 percent of the total watershed area. The Ef for those models ranged from 0.41 to 0.71 .

Beyond the application to karst regions in Kentucky (Taylor and others, 2012), the TOPMODEL application has been used successfully to study a wide variety of hydrologicresearch topics, including topographic effects on water quality (Wolock, 1988; Wolock and others, 1989, 1990), topographic effects on streamflow (Beven and Wood, 1983; Beven and others, 1984; Kirkby, 1986), spatial-scale effects on hydrologic processes (Sivapalan and others, 1987; Wood and others, 1988, 1990; Famiglietti and Wood, 1991; Famiglietti, 1992), and the geomorphic evolution of watersheds (IjjászVásquez and others, 1992). TOPMODEL also has been used for estimating flood frequency (Beven, 1986a and b), effects of climate change on hydrologic processes (Wolock and Hornberger, 1991), carbon budgets (Band and others, 1991), base-flow residence times (Vitvar and others, 2002), and ecological-flow factors (Kennen and others, 2008).

The spatial datasets required for WATER-TOPMODEL were created, as described in "Dataset Preparation," and processed for the existing TOPMODEL approach within WATER (Taylor and others, 2012); the model results from WATERTOPMODEL were then evaluated through comparison with existing USGS streamflow data as noted below.

The process-based model returned statistically significant results, comparable to both Williamson and others (2009) and Taylor and others (2012), and met the requirements of the project; therefore, the underlying process-based approach and computer code were not modified beyond that described in Taylor and others (2012). However, as calibration to specific local input data can typically improve a model's results, the Parameter Estimation software (PEST) model by Gallagher and Doherty (2007) was applied to the WATER-TOPMODEL simulations at Lost River near Leipsic, Ind., and Lost River near Prospect, Ind. Note that PEST could not be run at Flood Creek at Orleans, Ind., as the streamgage was relatively new and there was no long-term streamflow data available for calibration purposes.

To create a WATER-TOPMODEL streamflow response model (Williamson and others, 2009; Taylor and others, 2012) for the karstic upper Lost River watershed study area (figs. 1 and 6), datasets were created for two simulation watersheds that correspond to the topographical catchments of two USGS streamgages located on Lost River near Leipsic and Prospect, Ind., respectively. The Leipsic simulation watershed measures drainage from an area of $35.36 \mathrm{mi}^{2}$ of which about 10 percent drains internally through sinkholes and sinking streams. The Leipsic simulation watershed drains a watershed tributary to the Lost River at Prospect. The Prospect simulation watershed drains an area of approximately $184.69 \mathrm{mi}^{2}$, is about 60 percent internally drained, and includes the towns of Orangeville and Orleans. Drainage in a small $\left(1.39 \mathrm{mi}^{2}\right)$ watershed, known locally as Flood Creek, located to the northeast of Orleans, Ind., also was simulated; however, no existing streamflow data were available to evaluate model results in this watershed (table 3). Computation of drainage areas in this study was conducted by using a variety of information and techniques and is described in detail in the section "Watershed Boundary Datasets."

\section{Dataset Preparation}

The WATER-TOPMODEL simulations conducted for this project are dependent on several spatial databases reformatted specifically for the study area as shown in figures 1 and 6. These databases include information about hydrography, topography, soils, and land-use data. Additionally, time-series datasets such as precipitation and temperature were obtained and processed from available sources. The datasets created and used as input to the WATER-TOPMODEL application are described in the following sections. 
Table 3. Simulation watersheds (with U.S. Geological Survey station identification numbers) and respective drainage areas as used for development of the Water Availability Tool for Environmental Resources (WATER)TOPMODEL application.

$\left[\mathrm{mi}^{2}\right.$, square mile; $\mathrm{km}^{2}$, square kilometer]

\begin{tabular}{lcccc}
\hline & $\begin{array}{c}\text { Total drainage area } \\
\text { above site } \\
\left(\mathbf{m i}^{2}\right)\end{array}$ & $\begin{array}{c}\text { Internally drained } \\
\text { area above site } \\
\left(\mathbf{m i}^{2}\right)\end{array}$ & $\begin{array}{c}\text { Total drainage area } \\
\text { above site } \\
\left.\mathbf{( k m}^{2}\right)\end{array}$ & $\begin{array}{c}\text { Internally drained } \\
\text { area above site } \\
\left(\mathbf{k m}^{2}\right)\end{array}$ \\
\hline $\begin{array}{l}\text { Lost River near Leipsic, Indiana } \\
(03373530)\end{array}$ & 35.36 & 3.47 & 91.58 & 8.99 \\
$\begin{array}{l}\text { Lost River near Prospect, Indiana } \\
(03373560)\end{array}$ & 184.69 & 103.60 & 478.34 & 268.33 \\
$\begin{array}{l}\text { Flood Creek at Orleans, Indiana } \\
(384019086270400)\end{array}$ & 1.39 & 1.39 & 3.59 & 3.59 \\
\hline
\end{tabular}

\section{Watershed Boundary Datasets}

Watershed boundaries were compiled for this study using topographically defined drainage divides, with additions or subtractions from adjacent areas that drained into the modeled area through subsurface karst features. Watershed boundaries used in the WATER-TOPMODEL simulations were created based on specific knowledge of karst groundwater flow within the upper Lost River watershed (dye-trace studies and so forth) determined from previous studies (Bayless and others, 1994; Malott, 1952, and Murdock and others, 1968). These watershed boundaries were not created by traditional topography-based methods and may produce simulation results that would be different from models based on the latter.

The watershed boundary for Flood Creek was established by using data presented in Taylor and Nelson (2008), which used DEM data and sinkhole point data to delineate drainage areas for sinkholes using specific methods described in the report. The Flood Creek watershed was delineated based on data from other sources that accounts for the complex karst hydrology in the region; the mapped pour point (or the lowest point in the delineated watershed to which all water drains) may not directly coincide with the actual location of the USGS streamflow-gaging station. This is the best approximation available given the complexity of the watershed.

The watershed boundary for the Lost River near Prospect was determined by using a standard delineation method, such as described in Jenson and Domingue (1988), using a flowdirection raster made from the DEM. Subsequent to creation, the watershed boundary was manually edited to remove some areas in the northern portion of the watershed that were proven to be non-contributing areas as defined in Bayless and others (1994).

The watershed boundary for Lost River near Leipsic was made by the standard delineation method using a flow-direction raster made from the DEM. This watershed boundary will be directly comparable to that created by other applications such as USGS StreamStats (Ries and others, 2008).

\section{Hydrographic Datasets}

Hydrographic datasets include both original and derived datasets. Original datasets of stream reaches within the upper Lost River watershed in Orange County, Ind., were obtained for the study area from the USGS National Hydrography Datasets (NHD+) (U.S. Geological Survey, 2011a) on a hydrologic unit code tile basis (http://nhd.usgs.gov/). The datasets were combined into a single derived dataset, and attributes were specifically added to support model execution and display.

\section{Topographic Datasets}

Topographic datasets include both original and derived datasets. Land-surface elevation is the original dataset and was obtained online from the USGS National Elevation Dataset (NED) (U.S. Geological Survey, 2011b). This original dataset was processed to create the following derived raster datasets; sink-filled elevation, karst-modified elevation, flow direction, flow accumulation, synthetic stream network, slope, and aspect. Several karst-specific raster datasets were derived to simplify the watershed and allow WATER-TOPMODEL to function properly; a sink-filled raster was created to smooth the landscape and allow water to flow downgradient, a karstmodified raster was created to ensure water from contributing areas outside of the topographically delineated watershed was accounted for, and a subsequent synthetic stream network was created to provide a continuous grid of stream cells that followed the derived topographic lows. Flow-accumulation and slope datasets were further processed to create the TWI raster that is used directly by the TOPMODEL component of WATER (Williamson and others, 2009; Taylor and others, 2012). 


\section{Soil Datasets}

Original soil datasets (SSURGO) were obtained online from the NRCS Soil Data Mart (now Web Soil Survey) (U.S. Department of Agriculture-Natural Resources Conservation Service, 2013) for Lawrence, Orange, and Washington Counties in the form of shapefiles and data tables tiled by county. These files were processed to create derived soil raster datasets including soil thickness, hydrologic soil group, saturated hydraulic conductivity, water holding capacity, clay percent, and field capacity. Additionally, as described in detail in Williamson and others (2009), computed WATER-TOP-

MODEL parameters in the form of raster datasets were created from the soil datasets for the study area

For example, the " $m$ " TOPMODEL scaling factor, which can be generally defined as the readily drained soil porosity over the rate of decrease with depth, is a key computed WATER-TOPMODEL soil-based parameter that is critical to the determination of soil saturation deficits and the generation of overland flows. The " $\mathrm{m}$ " parameter was computed from the SSURGO datasets (equation 2) and converted into a raster dataset for use in WATER-TOPMODEL.

According to Williamson and others (2009), the high and low values for saturated hydraulic conductivity $\left(\mathrm{K}_{\text {sat }}\right)$ were reported in SSURGO in addition to the representative value. The highest $\mathrm{K}_{\text {sat }}$ value for the soil-mapping unit was identified from the $\mathrm{K}_{\text {sat }}$-high data for the surface layer. The lowest $\mathrm{K}_{\text {sat }}$ value for the soil-mapping unit was identified from the $\mathrm{K}_{\text {sat }}{ }^{-}$ low data for the bottom layer (as defined by the soil thickness).

The conductivity multiplier (conmult) for each soil-mapping unit was calculated as follows:

where

$$
\text { conmult }=\frac{K_{\text {sat }}-\text { high }_{\text {surface }}}{K_{\text {sat }}-\text { low }_{\text {bottom }}}
$$

$$
\begin{gathered}
\mathrm{K}_{\text {sat }}-\text { high } \mathrm{surface}_{\text {is the high } \mathrm{K}_{\text {sat }} \text { value for the surface layer }} \\
\text { and } \\
\mathrm{K}_{\text {sat }}-\text { low }_{\text {bottom }} \begin{array}{c}
\text { is the low } \mathrm{K}_{\text {sat }} \text { value for the bottommost } \\
\text { soil layer for which the representative } \\
\mathrm{K}_{\text {sat }}>1 \text { micrometer per second. }
\end{array}
\end{gathered}
$$

The scaling parameter $(\boldsymbol{m})$ was then calculated for each soilmapping unit:

where

$$
f=\frac{\ln \text { conmult }}{\text { soil thickness }}
$$

and

$$
m=\frac{\text { porosity }- \text { field capacity }}{f}
$$

Land-Use Dataset

Land-use data for the simulations were obtained from the 2006 National Land Cover Dataset as contained in the Multi-Resolution Land Characteristics Consortium (MRLC) datasets (U.S. Geological Survey, 2011c) (Homer and others, 2012). This dataset was processed to create derived datasets of separate land uses that included forest, agricultural land, urban land, and roads.

\section{Precipitation and Temperature Datasets}

Using a shapefile for the study area, time-series observations for precipitation and temperature were obtained for available time intervals for sites within the study area. Datasets were downloaded from the USGS Geo Data Portal webpage (U.S. Geological Survey, 2011d) for North Central River Forecasting Center at a 4-kilometer $(\mathrm{km})$ resolution from June 15, 2000 to July 31, 2011. The time step was 1 day, and precipitation files contained depths in units of millimeters $(\mathrm{mm})$ and temperature units in degrees Kelvin.

\section{Observed Flow Time-Series Datasets}

Time-series datasets of historic streamflow measurements were obtained from the USGS NWIS and reformatted for use in WATER. Datasets were obtained for the available time periods at the Lost River near Leipsic and at the Lost River near Prospect. These datasets were used in the calibration and evaluation of simulations discussed in the following section. Note that data from the Flood Creek at Orleans streamgage were not used as the streamgage was new and could not provide a long enough period of record to make any significant determinations regarding model performance; therefore, data from this streamgage were not used for this study.

\section{Model Execution and Evaluation}

The WATER-TOPMODEL application was constructed and run as outlined in Taylor and others (2012), and the differences between measured and simulated data are presented in figures 7-11. Overall model performance is shown by boxplots that relate initial and optimized simulations to USGS streamgage data (fig. 7). Measured and simulated hydrographs at individual sites are presented in figures 8-11.

Statistical indicators of concurrence between simulated and measured discharges also were computed. A correlation coefficient of 0.36 and an Ef of 0.32 were obtained for the Lost River near Leipsic, Ind., simulation watershed (fig. 8). A correlation coefficient of 0.49 and an Ef of 0.28 were obtained for the Lost River near Prospect, Ind., simulation watershed (fig. 9). Correlation and Ef values that are closer to 1 indicate better agreement between the measured data and the model results. An $\mathrm{Ef}=0$ indicates that the simulated flow values are no more accurate than using a mean-flow value; an $\mathrm{Ef}<0$ indicates that the mean-flow value is more accurate than the model results (Nash and Sutcliffe, 1970; McCuen and others, 2006). 


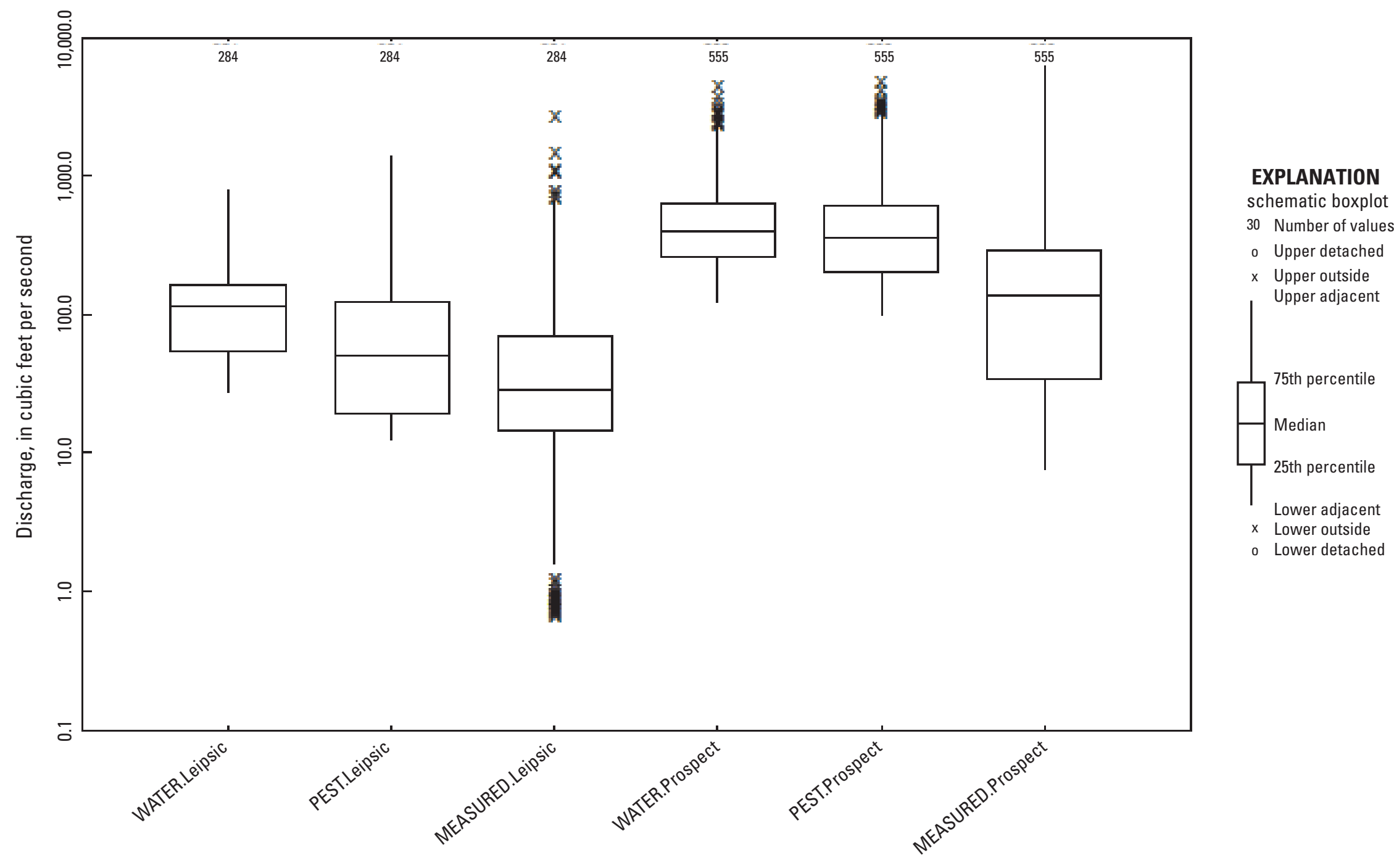

Figure 7. Statistical distribution for simulated, optimized, and measured streamflow data for Lost River near Leipsic and Prospect watersheds, Indiana (03373530 and 03373560, respectively). 


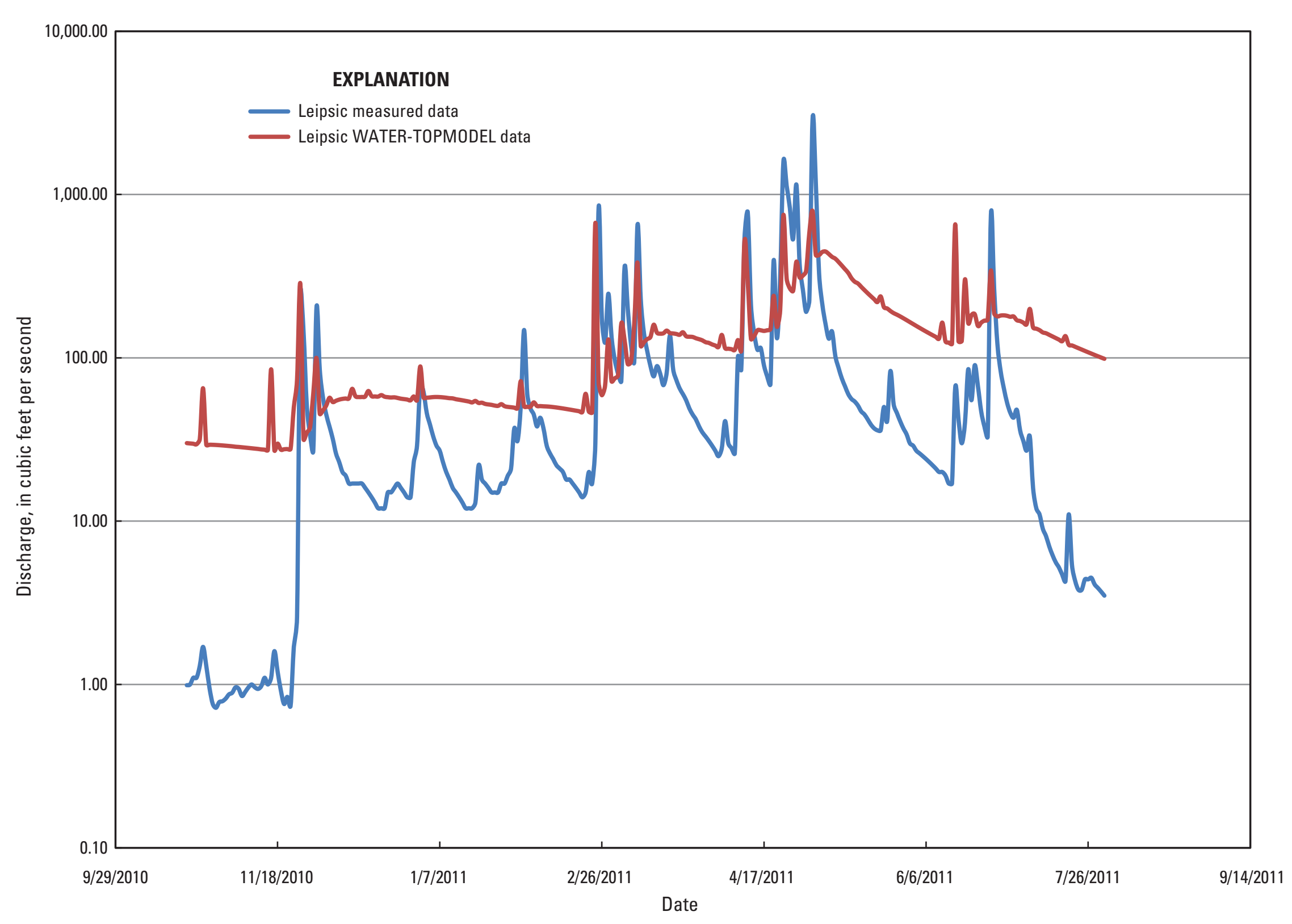

Figure 8. Measured versus simulated hydrographs (from the U.S. Geological Survey WATER-TOPMODEL application) for the Lost River near Leipsic, Indiana (03373530), simulation watershed. 


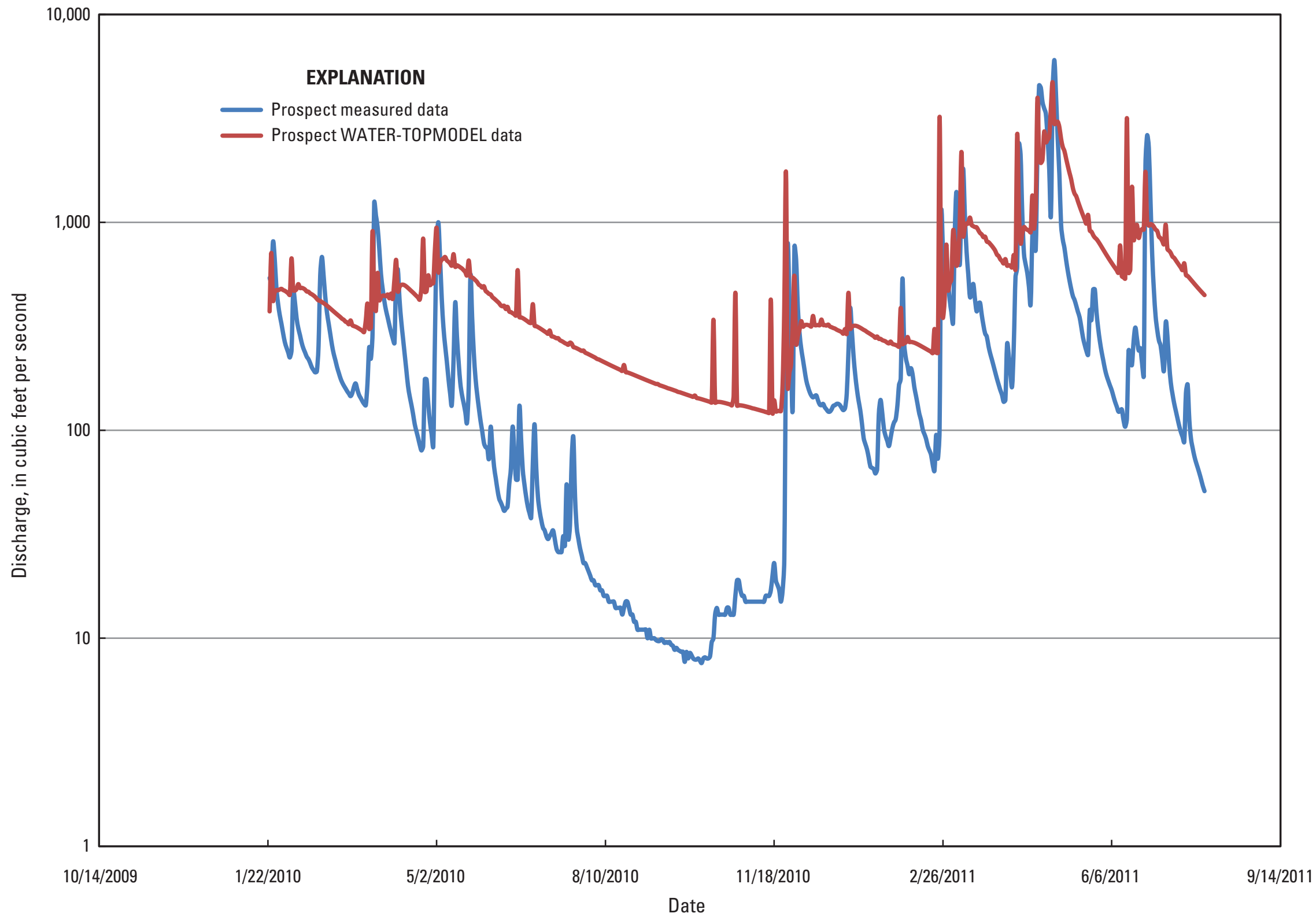

Figure 9. Measured versus simulated hydrographs (from the U.S. Geological Survey WATER-TOPMODEL application) for the Lost River near Prospect, Indiana (03373560), simulation watershed. 


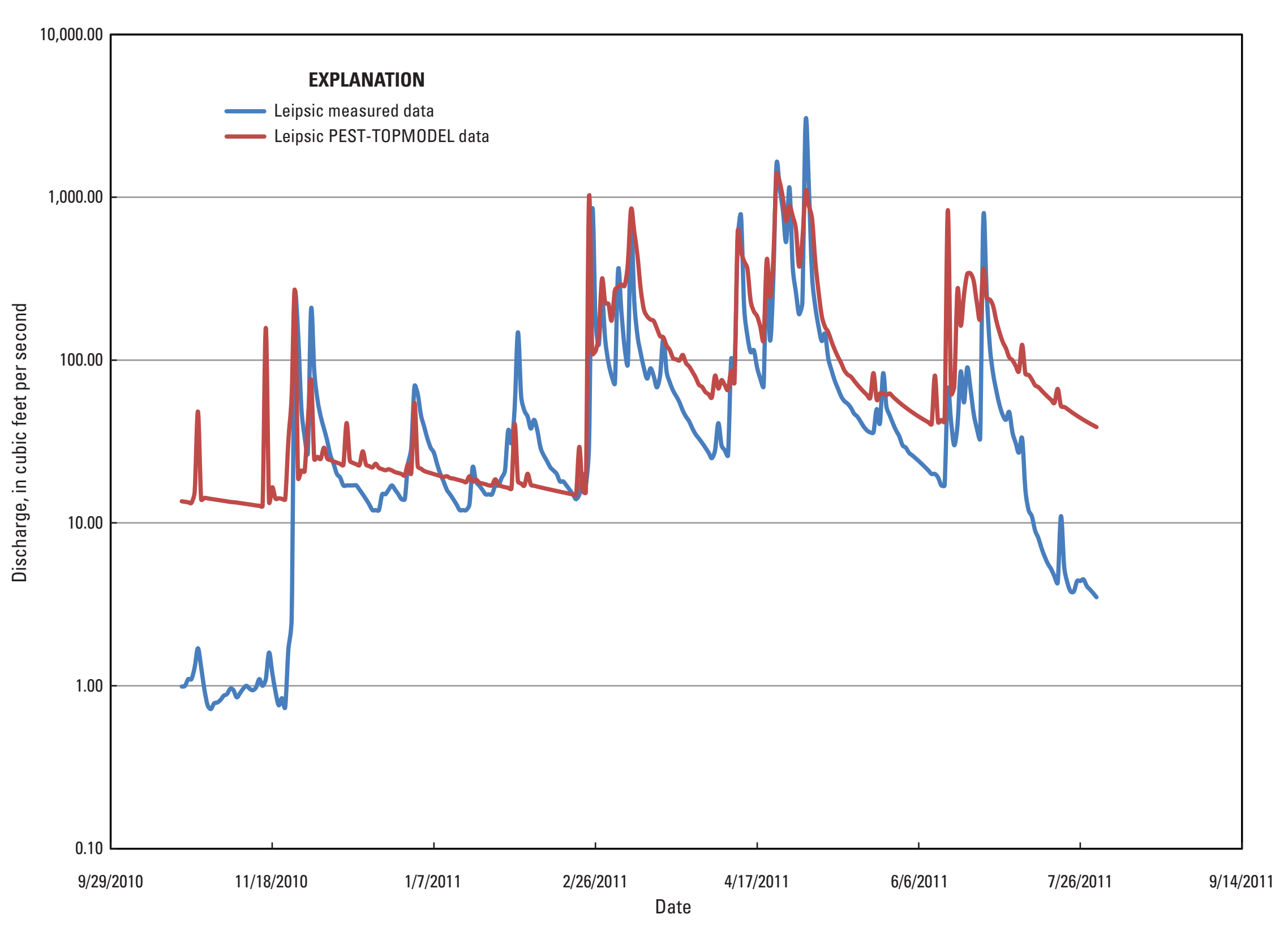

Figure 10. Measured versus Parameter Estimation software (PEST)-optimized simulated hydrographs (from the U.S. Geological Survey WATER-TOPMODEL application) for the Lost River near Leipsic, Indiana (03373530), simulation watershed. 


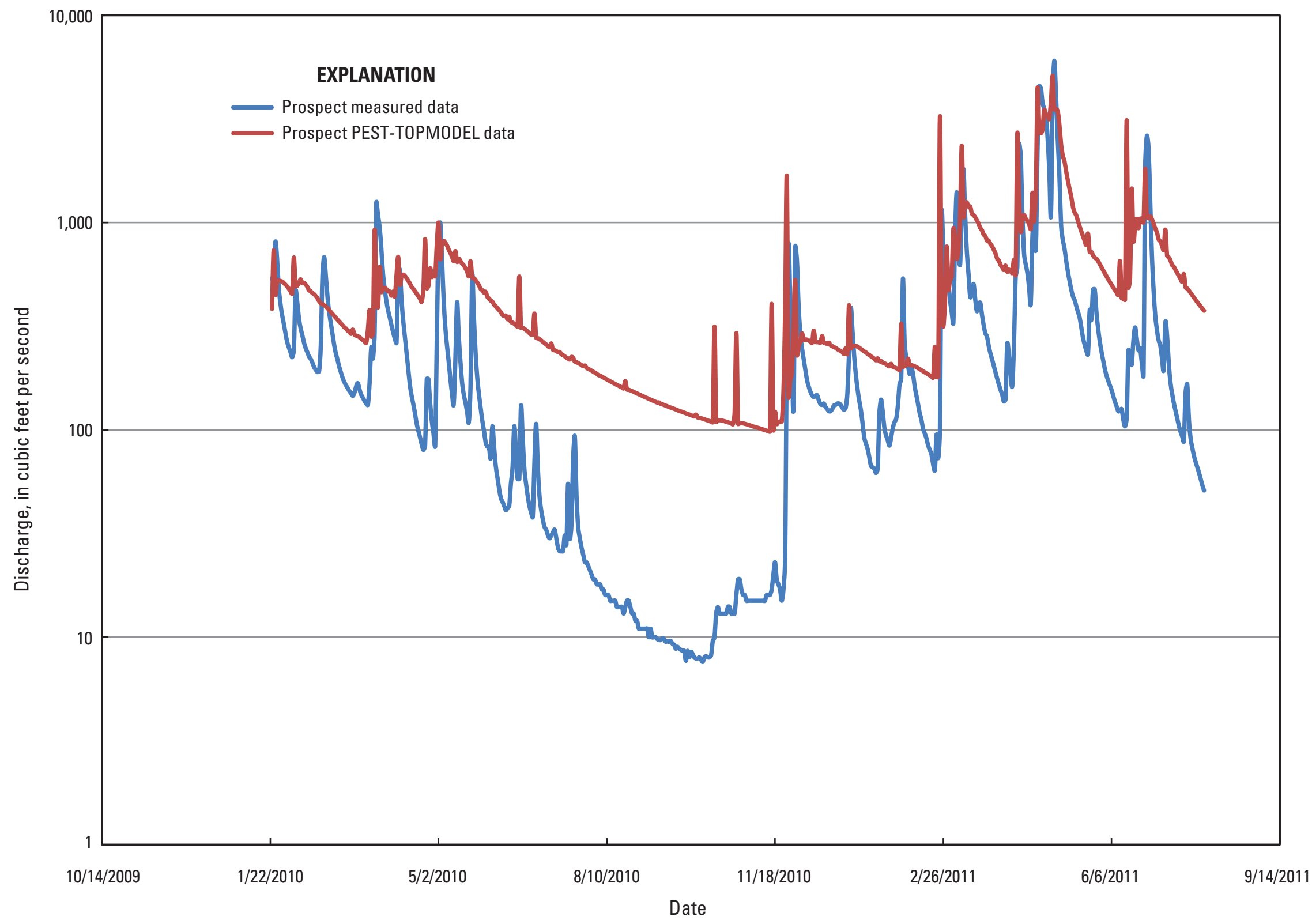

Figure 11. Measured versus Parameter Estimation software (PEST)-optimized simulated hydrographs (from the U.S. Geological Survey WATER-TOPMODEL application) for the Lost River near Prospect, Indiana (03373560), simulation watershed. 
The PEST tool (Gallagher and Doherty, 2007) also was used in conjunction with WATER-TOPMODEL to determine if slight adjustments to model parameter values could statistically improve the agreement between measured and modeled stream discharges. PEST functions by executing many iterations of a model (in this case TOPMODEL) and optimizes the results by slightly changing specified model parameters with each iteration, minimizing the differences between measured and simulated values, and identifying the set of model parameters that most closely simulates the measured data.

For the purposes of this study, two WATER-TOPMODEL parameters were identified for optimization. The parameters optimized by using PEST were (1) the rooting-depth factor that strongly controls evapotranspiration and base flows; rooting depth can realistically vary by region and (or) type of vegetation; and (2) the TOPMODEL scaling factor ' $m$ ' that controls the soils-based runoff character of the watershed; $m$ has traditionally been modified to better account for regional or data-derived variability. All other parameters were held constant during the PEST simulations; other parameters used by WATER-TOPMODEL were not used for the PEST-derived calibration because they were typically components of ' $\mathrm{m}$ ' (such as $\mathrm{K}_{\text {sat }}$ ), were components of established subroutines (such as TR-55 (U.S. Department of Agriculture-Natural Resources Conservation Service, 1986)), or would not alter the underlying TOPMODEL processes being calibrated (such as precipitation amounts). The optimized values of the rooting depth and ' $m$ ' parameters were determined to be within reasonable limits of expectations for the study area. The values of all other parameters were held constant (tables 4-7).

The application of PEST to the TOPMODEL simulations for the upper Lost River watershed resulted in the improvement of some statistics. Optimized statistics from the PESTderived model runs for Lost River near Leipsic, Ind., yielded a correlation coefficient of 0.58 , and an Ef of 0.56 . Statistics for optimized simulation at the Lost River near Prospect, Ind., returned a correlation coefficient of 0.60 , and an Ef of 0.39 .

The measured hydrographs and those generated using the optimized parameter set, as with the original parameter set, showed streamflow responses to storm events of similar timing and magnitude (figs. 10 and 11). As with the original parameter set, a systematic high bias is present among all model runs and is most notable under low-flow conditions. The improvement in simulation results realized by using PEST, however, can be seen in comparing the relative amount of bias present in hydrographs using optimized and original parameter values. The PEST-optimized model for Lost River at Leipsic, Ind., was the best of those produced.

The use of parameters established for this study area should be applied to other study areas with extreme caution because the hydrologic variability, particularly as a result of the karst setting, will likely cause the parameter values to be relatively unique. The best simulation results will likely be produced where the WATER-TOPMODEL parameters are optimized using USGS streamflow-gaging station data within gaged watersheds of limited extent.

\section{Model Limitations and Qualifications}

The WATER-TOPMODEL simulations for this project were created as described in Williamson and others (2009) and Taylor and others (2012). The limitations of the WATER-TOPMODEL approach also were described in those earlier reports. In general, this model is an idealization based on mathematical equations that attempt to explain physical phenomena. A key limitation for any model results obtained by use of watershedaveraged parameters is that they do not fully capture all of the variability that is present within the watershed. For example, subtle spatial differences in soil properties and rainfall intensity that may affect the simulation results are not captured by watershed-averaged parameters. Future improvements to data resolution that include the use of light detection and ranging (LiDAR) and improved soils and land-use data should benefit simulation accuracy.

The extreme variability present within karst watersheds may make the use of parameters derived for this study area improper for application to other karst settings. The statistical evaluation of the WATER-TOPMODEL simulations generated for the upper Lost River watershed, however, indicates that this model can be successfully applied to some regional settings. Additional data-collection activities, such as flow-path delineation using dye traces, and modifications to the conceptual model could improve simulation results and provide a tool that will work spatially, under a wide range of conditions, and could be used for future planning purposes. 
Table 4. Water Availability Tool for Environmental Resources (WATER) input parameters for internally drained parts of Lost River watershed near Leipsic, Indiana (03373530), model after optimization with Parameter Estimation software (PEST) application (details of WATER-TOPMODEL parameters provided in Williamson and others (2009) and Taylor and others (2012)).

[Mgal/yr, million gallons per year; in., inch; in/h, inch per hour; $\mathrm{m}$, scaling parameter; mm, millimeter; USDA-NRCS, U.S. Department of Agriculture-Natural Resources Conservation Service]

\begin{tabular}{|c|c|c|c|}
\hline $\begin{array}{l}\text { WATER-TOPMODEL } \\
\text { parameter }\end{array}$ & Unit & $\begin{array}{l}\text { PEST-derived } \\
\text { value }\end{array}$ & $\begin{array}{l}\text { Regional values } \\
\text { from Taylor and } \\
\text { others (2012) }\end{array}$ \\
\hline Lake delay & Days & 1.5 & 1.5 \\
\hline Groundwater withdrawal & $\mathrm{Mgal} / \mathrm{yr}$ & 0 & 0 \\
\hline Surface-water withdrawal & $\mathrm{Mgal} / \mathrm{yr}$ & 0 & 0 \\
\hline Surface-water discharge & $\mathrm{Mgal} / \mathrm{yr}$ & 0 & 0 \\
\hline Conductivity multiplier & Unitless & 2.860096 & 2.860096 \\
\hline Water holding capacity & Decimal & 0.138852 & 0.138852 \\
\hline Wetness index adjustment & Unitless & 1 & 1 \\
\hline Soil depth & in. & $1,776.555$ & $1,776.555$ \\
\hline Percent macropore flow & Percent & 0.2 & 0.2 \\
\hline Field capacity & Decimal & 0.64 & 0.64 \\
\hline Saturated hydraulic conductivity & in $/ \mathrm{h}$ & 640.3544 & 640.3544 \\
\hline Porosity & Decimal & 0.385675 & 0.385675 \\
\hline Rooting-depth factor (percent of soil depth) & Percent & 0.85 & 0.16 \\
\hline m TOPMODEL scaling factor & $\mathrm{mm}$ & 440.253 & 126.755 \\
\hline Spatial coefficient (adjust $\mathrm{m}$ as a function of data resolution) & Unitless & 1 & 1 \\
\hline Impervious cover percent & Percent & 0.559046 & 0.559046 \\
\hline Road impervious cover percent & Percent & 5.657514 & 5.657514 \\
\hline Effective impervious cover percent & Percent & 0.7 & 0.7 \\
\hline Impervious runoff delay constant & Unitless & 0.1 & 0.1 \\
\hline Evapotranspiration exponent & Unitless & 0 & 0 \\
\hline Snowmelt coefficient & Unitless & 3 & 3 \\
\hline Rain on snow coefficient & Unitless & 8.23 & 8.23 \\
\hline TR-55 Impervious curve number (USDA-NRCS, 1986) & Unitless & 98 & 98 \\
\hline
\end{tabular}


Table 5. Water Availability Tool for Environmental Resources (WATER) input parameters for unallocated drainage of Lost River near Leipsic, Indiana (03373530), model after optimization with Parameter Estimation software (PEST) application (details of WATER-TOPMODEL parameters provided in Williamson and others (2009) and Taylor and others (2012)).

[Mgal/yr, million gallons per year; in., inch; in/h, inch per hour; $\mathrm{m}$, scaling parameter; mm, millimeter; USDA-NRCS, U.S. Department of Agriculture-Natural Resources Conservation Service]

\begin{tabular}{|c|c|c|c|}
\hline $\begin{array}{l}\text { WATER-TOPMODEL } \\
\text { parameter }\end{array}$ & Unit & $\begin{array}{l}\text { PEST-derived } \\
\text { value }\end{array}$ & $\begin{array}{c}\text { Regional values } \\
\text { from Taylor and } \\
\text { others (2012) }\end{array}$ \\
\hline Lake delay & Days & 1.5 & 1.5 \\
\hline Groundwater withdrawal & $\mathrm{Mgal} / \mathrm{yr}$ & 0 & 0 \\
\hline Surface-water withdrawal & $\mathrm{Mgal} / \mathrm{yr}$ & 0 & 0 \\
\hline Surface-water discharge & $\mathrm{Mgal} / \mathrm{yr}$ & 0 & 0 \\
\hline Conductivity multiplier & Unitless & 2.598053 & 2.598053 \\
\hline Water holding capacity & Decimal & 0.128484 & 0.128484 \\
\hline Wetness index adjustment & Unitless & 1 & 1 \\
\hline Soil depth & in. & $1,953.921$ & $1,953.921$ \\
\hline Percent macropore flow & Percent & 0.2 & 0.2 \\
\hline Field capacity & Decimal & 0.315075 & 0.315075 \\
\hline Saturated hydraulic conductivity & in $/ \mathrm{h}$ & 477.3988 & 477.3988 \\
\hline Porosity & Decimal & 0.382866 & 0.382866 \\
\hline Rooting-depth factor (percent of soil depth) & Percent & 0.84 & 0.16 \\
\hline m TOPMODEL scaling factor & $\mathrm{mm}$ & 27.33 & 154.4868 \\
\hline Spatial coefficient (adjust $m$ as a function of data resolution) & Unitless & 1 & 1 \\
\hline Impervious cover percent & Percent & 0.296579 & 0.296579 \\
\hline Road impervious cover percent & Percent & 3.722091 & 3.722091 \\
\hline Effective impervious cover percent & Percent & 0.7 & 0.7 \\
\hline Impervious runoff delay constant & Unitless & 0.1 & 0.1 \\
\hline Evapotranspiration exponent & Unitless & 0 & 0 \\
\hline Snowmelt coefficient & Unitless & 3 & 3 \\
\hline Rain on snow coefficient & Unitless & 8.23 & 8.23 \\
\hline TR-55 Impervious curve number (USDA-NRCS, 1986) & Unitless & 98 & 98 \\
\hline
\end{tabular}


Table 6. Water Availability Tool for Environmental Resources (WATER) input parameters for internally drained parts of Lost River watershed near Prospect Indiana (03373560), model after optimization with Parameter Estimation software (PEST) application (details of WATER-TOPMODEL parameters provided in Williamson and others (2009) and Taylor and others (2012)).

[Mgal/yr, million gallons per year; in., inch; in/h, inch per hour; $\mathrm{m}$, scaling parameter; mm, millimeter; USDA-NRCS, U.S. Department of Agriculture-Natural Resources Conservation Service]

\begin{tabular}{|c|c|c|c|}
\hline $\begin{array}{l}\text { WATER-TOPMODEL } \\
\text { parameter }\end{array}$ & Unit & $\begin{array}{l}\text { PEST-derived } \\
\text { value }\end{array}$ & $\begin{array}{l}\text { Regional values } \\
\text { from Taylor and } \\
\text { others (2012) }\end{array}$ \\
\hline Lake delay & Days & 1.5 & 1.5 \\
\hline Groundwater withdrawal & $\mathrm{Mgal} / \mathrm{yr}$ & 0 & 0 \\
\hline Surface-water withdrawal & $\mathrm{Mgal} / \mathrm{yr}$ & 0 & 0 \\
\hline Surface-water discharge & $\mathrm{Mgal} / \mathrm{yr}$ & 0 & 0 \\
\hline Conductivity multiplier & Unitless & 3.466621 & 3.466621 \\
\hline Water holding capacity & Decimal & 0.143074 & 0.143074 \\
\hline Wetness index adjustment & Unitless & 1 & 1 \\
\hline Soil depth & in. & $1,374.007$ & $1,374.007$ \\
\hline Percent macropore flow & Percent & 0.2 & 0.2 \\
\hline Field capacity & Decimal & 0.320966 & 0.320966 \\
\hline Saturated hydraulic conductivity & in $/ \mathrm{h}$ & 683.5024 & 683.5024 \\
\hline Porosity & Decimal & 0.390479 & 0.390479 \\
\hline Rooting-depth factor (percent of soil depth) & Percent & 0.16 & 0.16 \\
\hline m TOPMODEL scaling factor & $\mathrm{mm}$ & 104.7961 & 104.7961 \\
\hline Spatial coefficient (adjust $\mathrm{m}$ as a function of data resolution) & Unitless & 1 & 1 \\
\hline Impervious cover percent & Percent & 0.628126 & 0.628126 \\
\hline Road impervious cover percent & Percent & 6.309387 & 6.309387 \\
\hline Effective impervious cover percent & Percent & 0.7 & 0.7 \\
\hline Impervious runoff delay constant & Unitless & 0.1 & 0.1 \\
\hline Evapotranspiration exponent & Unitless & 0 & 0 \\
\hline Snowmelt coefficient & Unitless & 3 & 3 \\
\hline Rain on snow coefficient & Unitless & 8.23 & 8.23 \\
\hline TR-55 Impervious curve number (USDA-NRCS, 1986) & Unitless & 98 & 98 \\
\hline
\end{tabular}


Table 7. Water Availability Tool for Environmental Resources (WATER) input parameters for unallocated drainage of Lost River near Prospect, Indiana (03373560), model after optimization with Parameter Estimation software (PEST) application (details of WATER-TOPMODEL parameters provided in Williamson and others (2009) and Taylor and others (2012)).

[Mgal/yr, million gallons per year; in., inch; in/h, inch per hour; $\mathrm{m}$, scaling parameter; mm, millimeter; USDA-NRCS, U.S. Department of Agriculture-Natural Resources Conservation Service]

\begin{tabular}{|c|c|c|c|}
\hline $\begin{array}{l}\text { WATER-TOPMODEL } \\
\text { parameter }\end{array}$ & Unit & $\begin{array}{l}\text { PEST-derived } \\
\text { value }\end{array}$ & $\begin{array}{c}\text { Regional values } \\
\text { from Taylor and } \\
\text { others (2012) }\end{array}$ \\
\hline Lake delay & Days & 1.5 & 1.5 \\
\hline Groundwater withdrawal & $\mathrm{Mgal} / \mathrm{yr}$ & 0 & 0 \\
\hline Surface-water withdrawal & $\mathrm{Mgal} / \mathrm{yr}$ & 0 & 0 \\
\hline Surface-water discharge & $\mathrm{Mgal} / \mathrm{yr}$ & 0 & 0 \\
\hline Conductivity multiplier & Unitless & 3.262332 & 3.262332 \\
\hline Water holding capacity & Decimal & 0.13754 & 0.13754 \\
\hline Wetness index adjustment & Unitless & 1 & 1 \\
\hline Soil depth & in. & $1,678.825$ & $1,678.825$ \\
\hline Percent macropore flow & Percent & 0.2 & 0.2 \\
\hline Field capacity & Decimal & 0.308042 & 0.308042 \\
\hline Saturated hydraulic conductivity & in $/ \mathrm{h}$ & 547.2441 & 547.2441 \\
\hline Porosity & Decimal & 0.386372 & 0.386372 \\
\hline Rooting-depth factor (percent of soil depth) & Percent & 0.89 & 0.16 \\
\hline m TOPMODEL scaling factor & $\mathrm{mm}$ & 61.07 & 141.7793 \\
\hline Spatial coefficient (adjust $m$ as a function of data resolution) & Unitless & 1 & 1 \\
\hline Impervious cover percent & Percent & 0.303413 & 0.303413 \\
\hline Road impervious cover percent & Percent & 3.623131 & 3.623131 \\
\hline Effective impervious cover percent & Percent & 0.7 & 0.7 \\
\hline Impervious runoff delay constant & Unitless & 0.1 & 0.1 \\
\hline Evapotranspiration exponent & Unitless & 0 & 0 \\
\hline Snowmelt coefficient & Unitless & 3 & 3 \\
\hline Rain on snow coefficient & Unitless & 8.23 & 8.23 \\
\hline TR-55 Impervious curve number (USDA-NRCS, 1986) & Unitless & 98 & 98 \\
\hline
\end{tabular}




\section{Surface-Water and Karst Groundwater Interactions}

Groundwater and surface water in a well-developed karst environment are nearly inseparable. The delay that separates precipitation infiltration from the streamflow response to base-flow discharge is generally much shorter in a karst setting than it is in aquifer systems dominated by primary porosity. The direct connection between groundwater and surface water in the upper Lost River watershed is likely the cause of steep rising limbs on stream hydrographs, short periods of base-flow recession, and other distinguishing characteristics.

Timing of streamflows at, or below, a confluence that is derived from multiple tributaries or conduits can result in hydrograph characteristics that are indicative of upstream or upgradient conditions. The Orangeville Rise at Orangeville, Ind. (USGS station 03373550), can be observed to exhibit double peaks when plotted by using higher-resolution continuous (15-minute) hydrographs (fig. 12); mean daily streamflow data alone may mask the observation of double-peak hydrographs as the timing of the peaks is often close (fig. 13). The double-peak hydrograph indicates that the peak flows from multiple sources are often out of phase. The observation of double peaks is likely indicative of two processes that should be noted for future mitigation efforts: the quick- and slow-flow components associated with karst-conduit systems and (or) time-of-travel variations in flows originating from different subwatersheds. The quick-flow component of a karst-driven hydrograph is the water that bypasses flow through the soil and aquifer matrix and quickly moves through the conduit to the outlet. The slow-flow component of the karst-driven hydrograph is the water that migrates (more slowly) through the soil and aquifer matrix. The effect of the double-peak hydrograph is likely a decreased maximum discharge, relative to the magnitude that might be observed by a single peak, as the total streamflow generated within the watershed is discharged over an extended period of time. The double-peak hydrographs may also mean that flood stages last longer than they would if multiple sources were discharging in phase. This observation may be important to stormwater management efforts.

The double-peak observation generally supports the interpretations of Murdock and Powell (1968), who divided the Lost River watershed into six groundwater subwatersheds on the basis of hydrologic and geomorphic characteristics with most of the current study area being contained in two subwatersheds that drain to the Orangeville Rise. The western subwatershed drains $9.4 \mathrm{mi}^{2}$ of the Crawford Upland, and the eastern subwatershed drains $31.3 \mathrm{mi}^{2}$ of sinkhole plain. Each of these respective watersheds may have different travel times to the Orangeville Rise based on the variability in precipitation, discharge, soil moisture, and conduit density within the respective drainage areas. Other unknown variables, such as the quick- and slow-flow components associated with karstconduit systems noted previously, will undoubtedly add to variability in time of concentration at the Orangeville Rise.

Groundwater wells in the region were monitored to gain an improved understanding of the surface-water and karst groundwater interactions in the watershed. The two wells used in this study (Ikerd Well (383932086281401) and the Marshall Farm Well (383840086301101) are located between Flood Creek at Orleans, Ind. (384019086270400), and Orangeville Rise at Orangeville, Ind. (03373550) (fig. 6). Comparing hydrographs of the two wells with that measured at Orangeville Rise indicates that the Marshall Farm Well is coupled to the conduit system driving flow at Orangeville Rise, but the Ikerd Well appears to be isolated from the conduits (fig. 14).

The variability in flow at the Orangeville Rise to karst groundwater response becomes more apparent when observing the interaction between the Marshall Farm Well, Orangeville Rise, and Flood Creek. The Marshall Farm Well is closely coupled to the conduit system underlying the dry-bed relic stream channels and karst paleovalleys and, therefore, relates to emerging streamflow from the Orangeville Rise, which drains that conduit system (fig. 14). However, the Marshall Farm Well represents one point only and wells completed in other, nearby conduits may not exhibit this same response. Water from the Flood Creek watershed enters the conduit system through upstream sinkholes and also drains to the Orangeville Rise through the underlying conduit system; therefore, this water will cause increases in both the streamflow emerging from the Orangeville Rise and the water-surface elevation in any connected conduits between the two points. While based on extremely limited data (only one well and a limited period of data collection with few large storms), an interesting observation is the interaction between the Orangeville Rise, the Marshall Farm Well, and Flood Creek, which are all hydrologically related (fig. 14).

A simple plot of hysteretic loops in the data was created for various storm peaks with overlapping data. Hysteretic loops are created by plotting one dataset against another over a peak and assessing the "loop" created by changes in timing and response of the two variables (Evans and others, 1999). These hysteretic loops are typically fair unless there is a change in the relative responses within the system. 


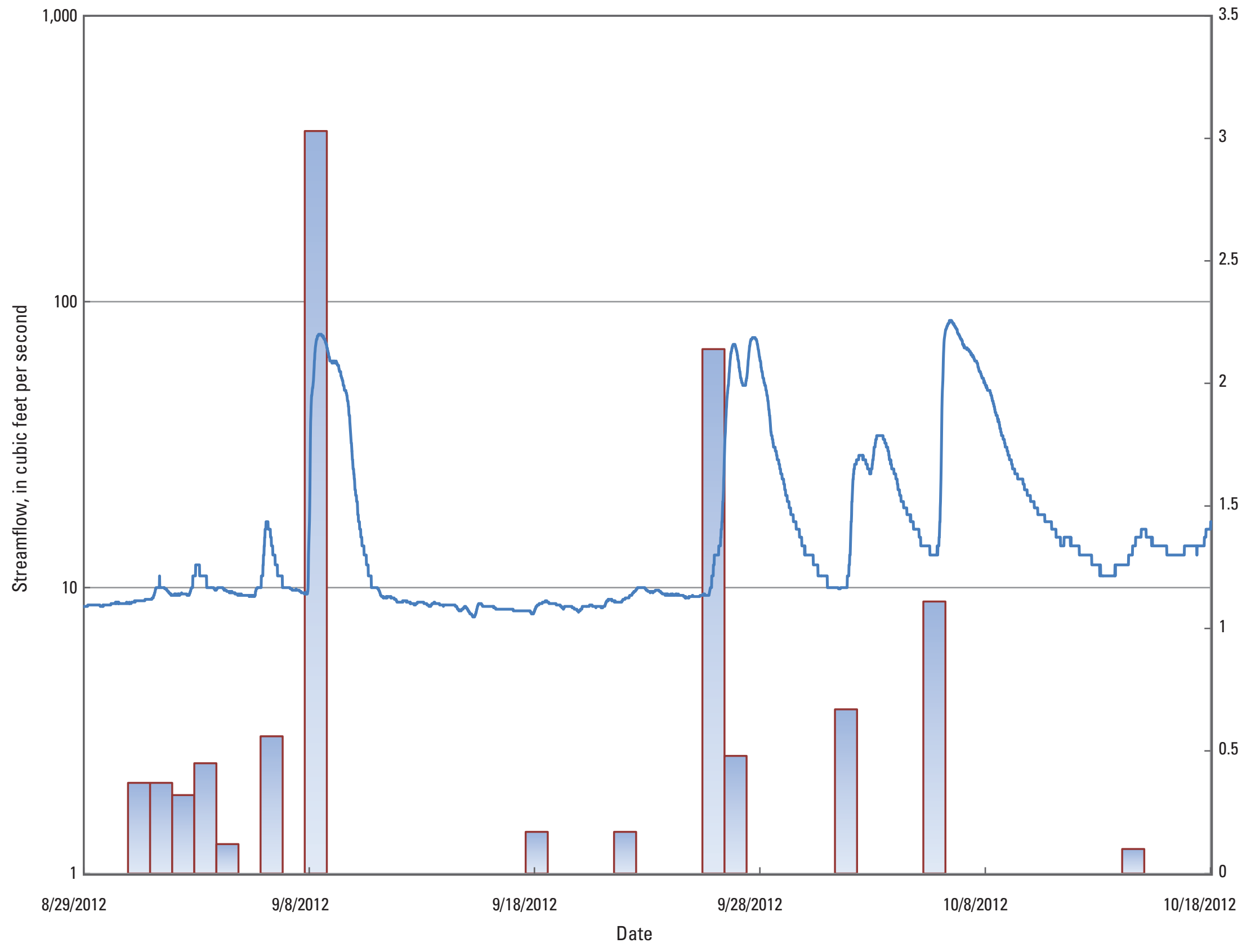

Figure 12. Daily precipitation and 15-minute unit value data for U.S. Geological Survey streamflow-gaging station 03373550 (Orangeville Rise at Orangeville, Indiana), showing double-peak nature of storm peaks and the lag time between rainfall and discharge from the spring. 


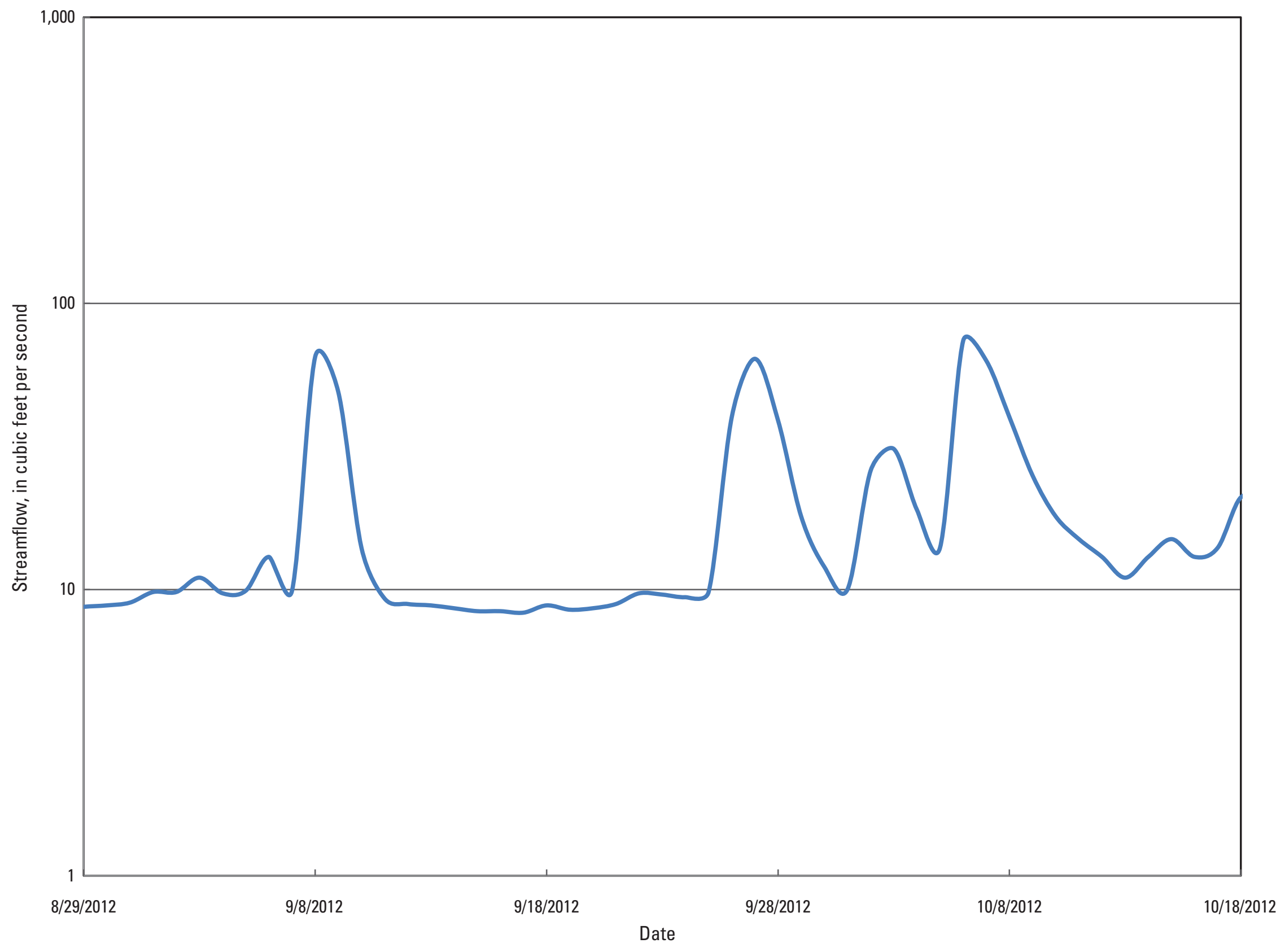

Figure 13. Mean daily data for U.S. Geological Survey streamflow-gaging station 03373550 (Orangeville Rise at Orangeville, Indiana), showing no double storm peaks owing to smoothing of the data. 


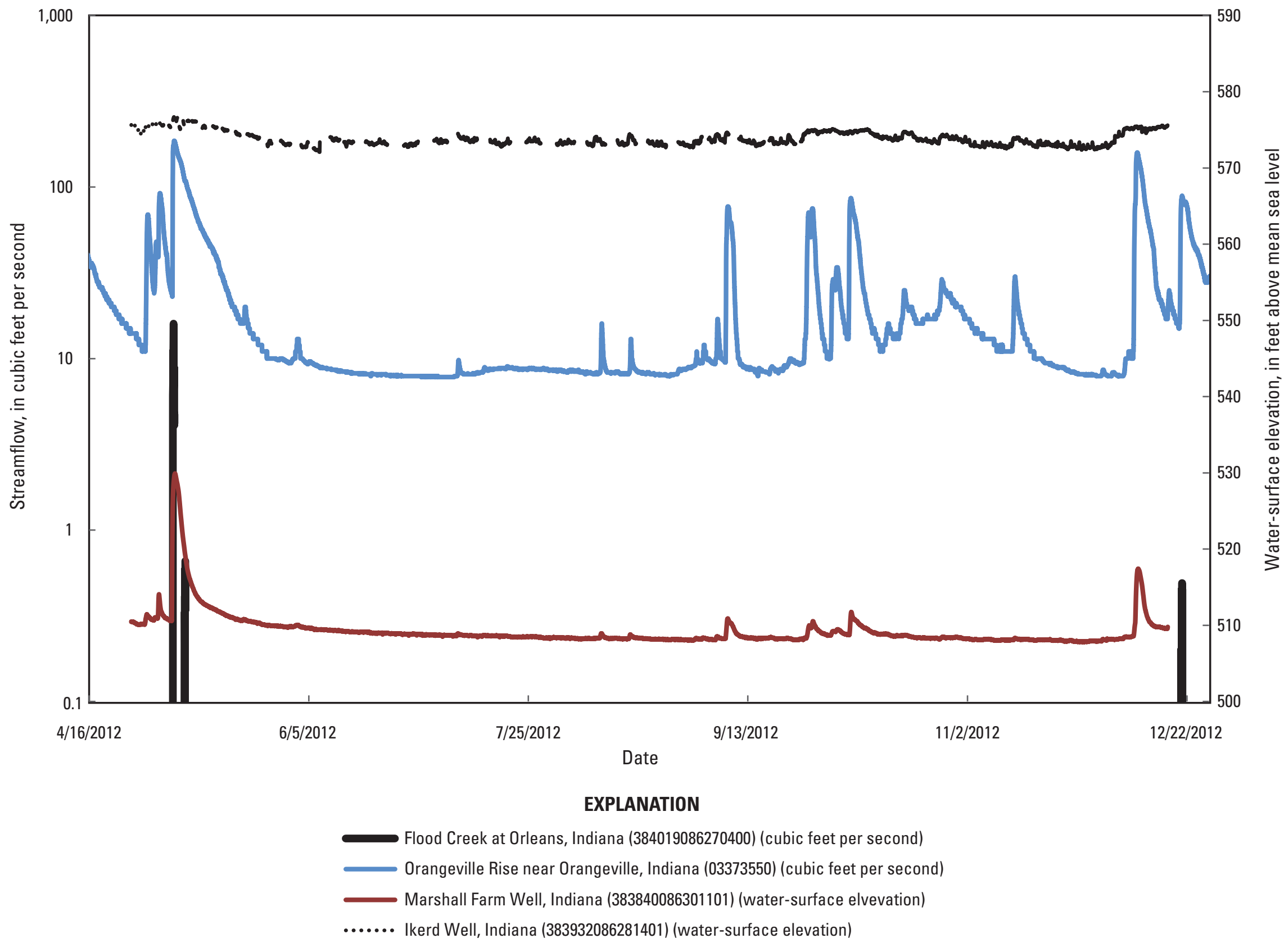

Figure 14. Streamflow at Orangeville Rise at Orangeville, Indiana (03373550), and Flood Creek at Orleans, Indiana (384019086270400), and water-surface elevation in the Marshall Farm Well, Indiana (38384008601101), and Ikerd Well, Indiana (383932086281401). 
The hysteresis plots for the Orangeville Rise and the Marshall Farm Well show a general counterclockwise loop indicating a slight lag in the groundwater peak compared to the surface-water discharge peak at the Orangeville Rise (figs. 15-18). The streamflow emerging from the Orangeville Rise begins to increase first and then water levels in the Marshall Farm Well begin to rise prior to both points showing a recession. These hysteretic loops may indicate that the outlet at Orangeville Rise is capable of discharging additional groundwater inputs to the system for most storm events, especially during dry periods when groundwater levels are depressed and the conduits have much available capacity.

The storm peak in early May 2012, however, shows a distinct "figure 8" pattern with an abrupt clockwise rotation early in the event related to a sharp rise in water levels in the Marshall Farm Well (fig. 19); the sharp rise observed in the groundwater level also corresponds to observed flows at Flood Creek (fig. 14). The Marshall Farm Well is located in close proximity to the Mather's stormwater rise (figs. 3 and 5); the Mather's stormwater rise is the primary overflow spring for the Orangeville Rise karst watershed, and storm drainage from Orleans combines with subsurface flow from the upstream contributing drainages to resurge at the Mather's stormwater rise. Given this, the rapid rise in groundwater level within the Marshall Farm Well is likely attributable, in part, to the observed contributions from the Flood Creek drainage. This observation then begins to confirm, in part, the connection between the upstream contributions within the watershed and the outlet at the Orangeville Rise. Given the limitations of the current data, this interaction can be noted only for these specific monitoring points at this time.

In order to further explore the relationship between subsurface conduit conditions and flow from the Orangeville Rise, the hydrograph at the Orangeville Rise was further assessed. A sliding-interval hydrograph-separation technique, described in Sloto and Crouse (1996), was applied to assist in defining a "base" or bounding condition. Sloto and Crouse (1996) offer different methods of hydrograph separation (fixed interval, local minimum, and sliding interval), and all three would have worked for this simple action of defining a bounding condition at the Orangeville Rise. The sliding-interval method, however, is less conservative than the local-minimum method and provides better resolution than the fixed-interval method and, therefore, provided a better graphical representation of the bounding condition.

Hydrograph-separation methods typically detail the base-flow and overland-flow (stormwater) components of a hydrograph that are not completely applicable in a karstic setting; however, this technique does begin to quantify the relative subsurface component of the system that is critical in understanding bounding conditions within a karst conduit. In effect, the percentage of flow that is identified as base flow in a hydrograph-separation analysis is indicative of water that is potentially supplied from storage in the underlying conduits. A conduit system that is nearer to full capacity will, therefore, exhibit a longer period of sustained, elevated base flow from the outlet as noted on the hydrograph. The risk of flooding after periods of prolonged high base flows will, consequently, be increased as water that cannot drain from the conduit system is gradually being stored and building up over time in the conduits.

During the period of record available for this specific analysis (November 2011-February 2013), and using a drainage area of $40.7 \mathrm{mi}^{2}$ as described previously, the total amount of base flow within the conduit system was estimated to be substantially higher during the winter months than during the summer. As a percentage, however, dryer periods of the summer showed relatively more base flow (table 8 and fig. 20). During periods of higher base flow, the conduit system is likely flowing at a higher volume and less able to handle additional contributions of water without exceeding the capacity of the conduit system and forcing flows into the surface relic-stream channels and (or) through the system of stormwater rises as flooding. During periods of higher, sustained base flows, additional flows from upstream in the watershed (such as those flows originating from the Flood Creek watershed) will potentially exacerbate this capacity issue; therefore, there could be a greater risk of flooding in the Orleans area when Orangeville Rise has exhibited longer periods of higher sustained base flows as this condition may indicate that there is insufficient storage to accommodate additional subsurface water without resultant surface flooding.

During or following intense or protracted rain, discharge at Orangeville Rise increases until it reaches a plateau of about $200 \mathrm{ft}^{3} / \mathrm{s}$ and then remains relatively stable, even as discharge continues to increase at other stations nearby (fig. 21). Similarly, the Lost River at CR100E, Lost River at CR500N, Lost River at CR525W, and Dry Branch at 525W (fig. 22) record flows (in typically dry channels) when the Orangeville Rise is showing sustained base flow near $200 \mathrm{ft}^{3} / \mathrm{s}$. This behavior indicates that there are limits on the hydraulic capacity of the conduits feeding the Orangeville Rise and that flow above those limits is diverted to other outlets such as the Mather's stormwater rise.

Just as water can "back up" and go into storage owing to restrictions and capacity limitations at the Orangeville Rise, water also can back up at other points and cause a ripple effect. When high flows occur in the Lost River (the perennial reach below Orangeville, Ind.), this condition also may cause water to back up at the Orangeville Rise owing to a process called hydraulic damming; hydraulic damming is simply defined as increased hydraulic pressure from water impeded by downstream restrictions acting as a barrier or dam to upstream flows. If the Lost River creates a hydraulic damming effect on the Orangeville Rise during periods of higher flows, this could, to some extent, add to the observed base flow at the Orangeville Rise. Additional data would assist in validating this concept as the current observations are based on relatively short periods that did not adequately represent a broad range of climatic or hydrologic conditions. 


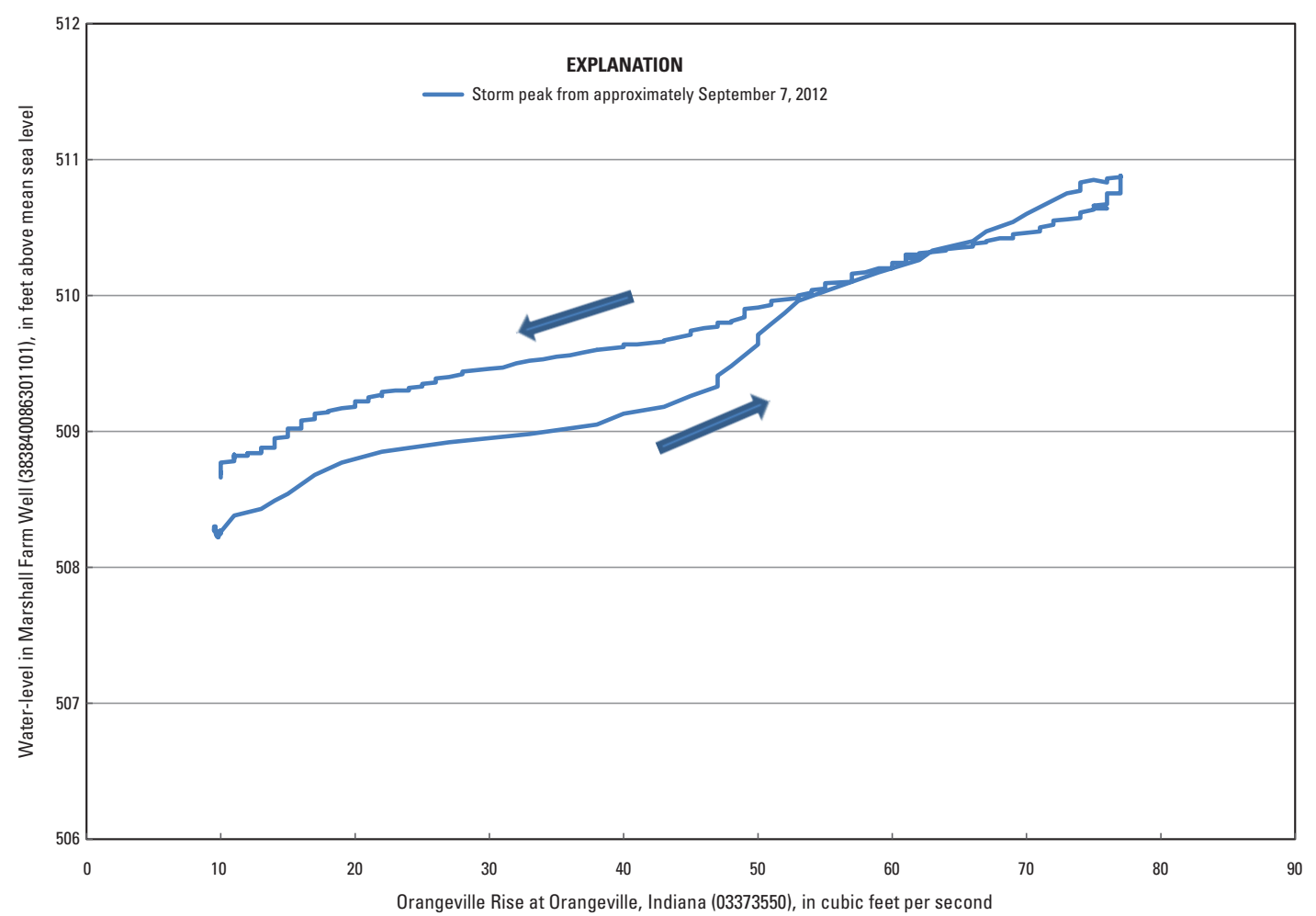

Figure 15. Fifteen-minute unit-value water levels in the Marshall Farm Well, Indiana (383840086301101), versus 15-minute unit-value streamflow originating from the Orangeville Rise, Indiana (03373550), showing a counterclockwise hysteresis that is indicative of the groundwater peak lagging slightly behind the surface-water peak for a storm peak starting on September 7, 2012.

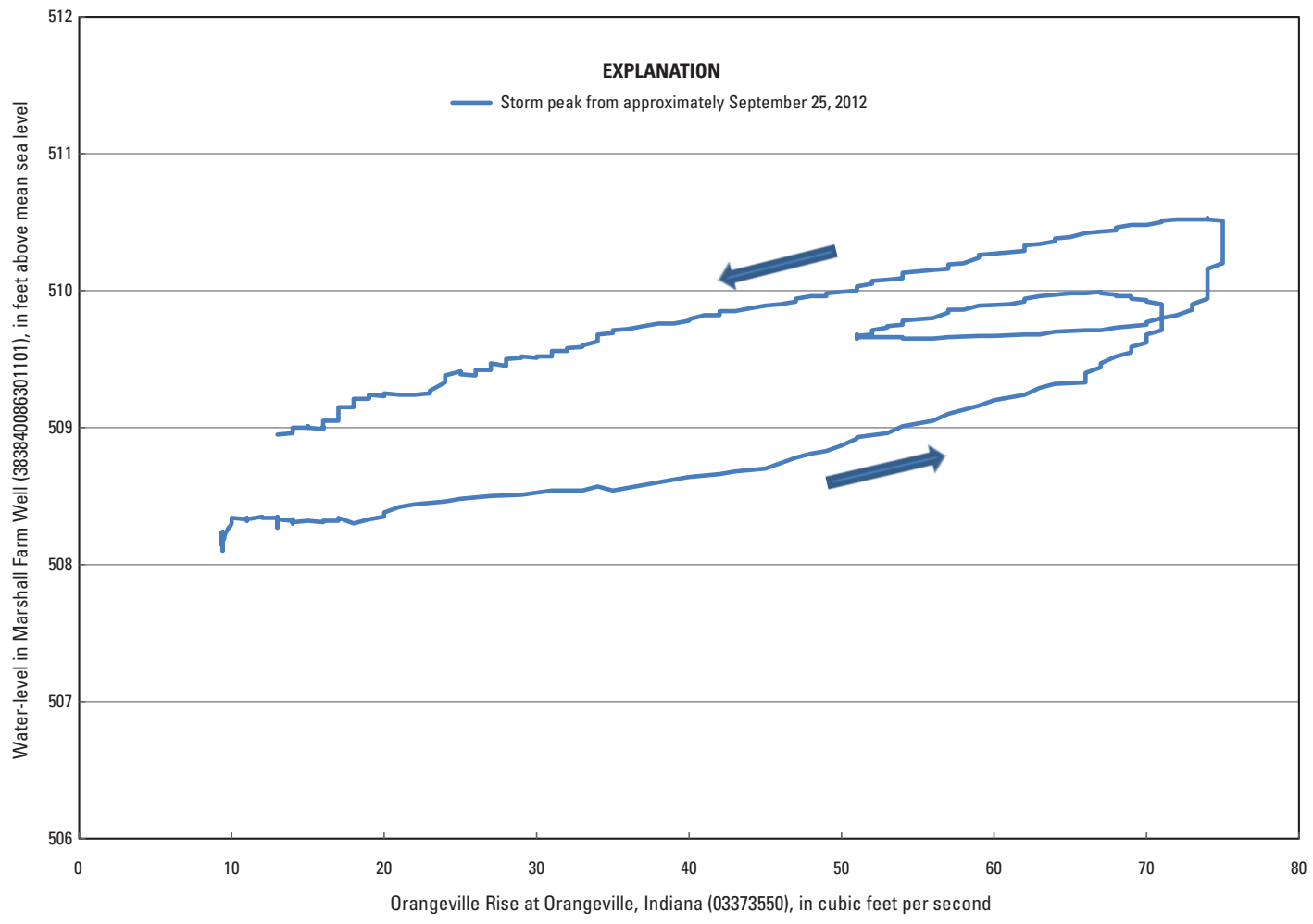

Figure 16. Fifteen-minute unit-value water levels in the Marshall Farm Well, Indiana (383840086301101), versus 15-minute unit-value streamflow originating from the Orangeville Rise, Indiana (03373550), showing a counterclockwise hysteresis that is indicative of the groundwater peak lagging slightly behind the surface-water peak for a storm peak starting on September 25, 2012. 


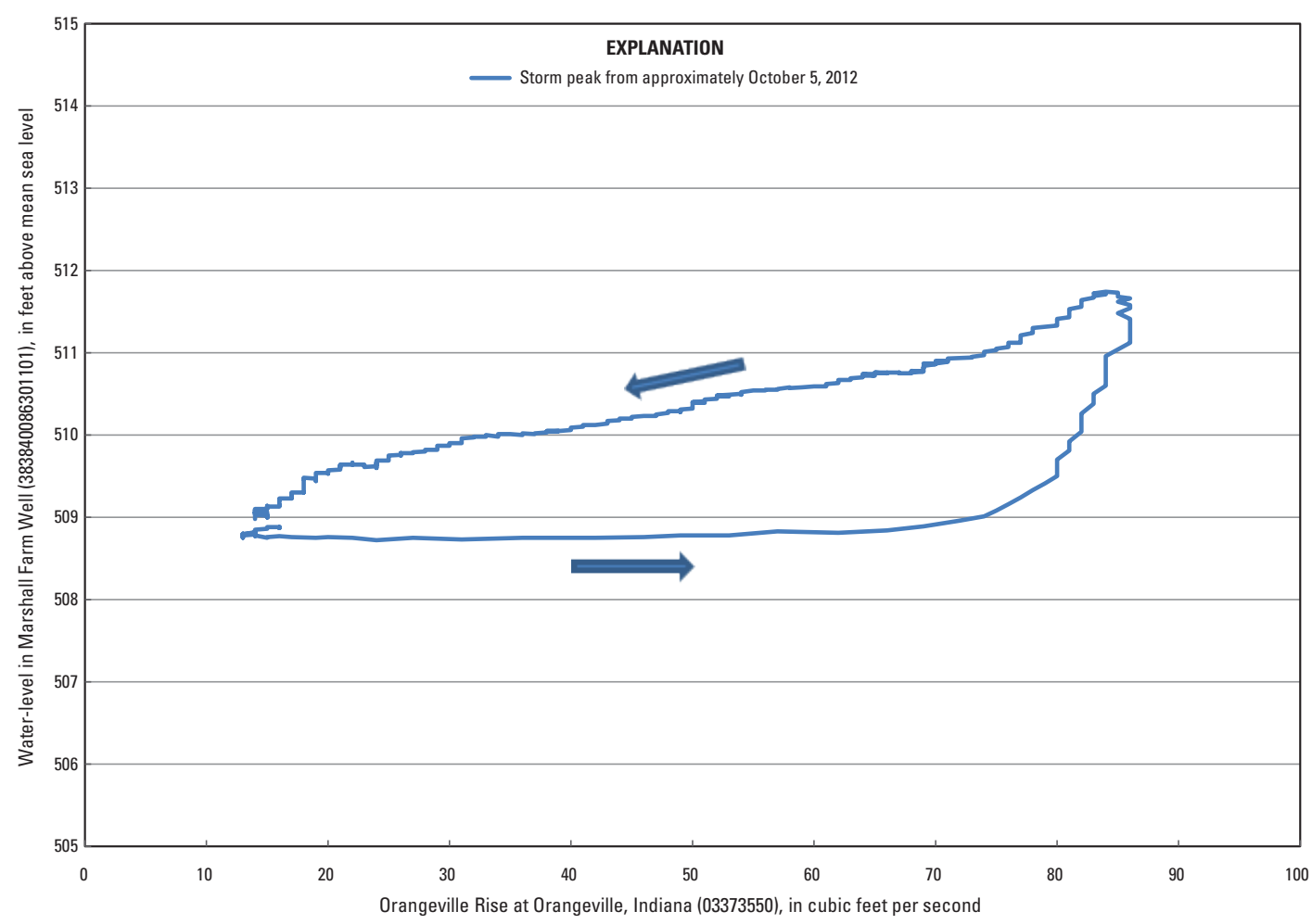

Figure 17. Fifteen-minute unit-value water levels in the Marshall Farm Well, Indiana (383840086301101), versus 15-minute unit-value streamflow originating from the Orangeville Rise, Indiana (03373550), showing a counterclockwise hysteresis that is indicative of the groundwater peak lagging slightly behind the surface-water peak for a storm peak starting on October 5, 2012.

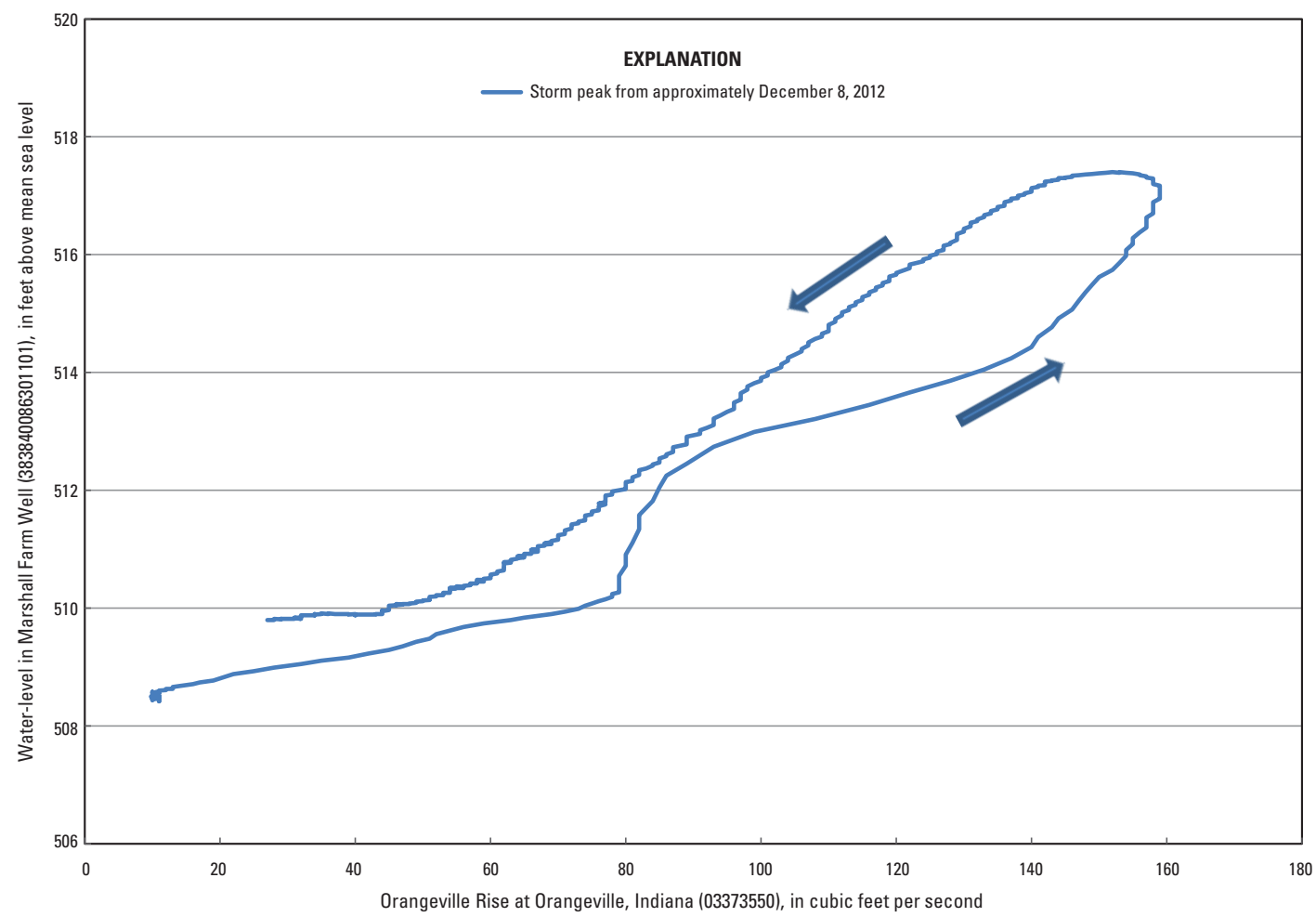

Figure 18. Fifteen-minute unit-value water levels in the Marshall Farm Well, Indiana (383840086301101), versus 15-minute unit-value streamflow originating from the Orangeville Rise, Indiana (03373550), showing a counterclockwise hysteresis that is indicative of the groundwater peak lagging slightly behind the surface-water peak for a storm peak starting on December 8, 2012. 


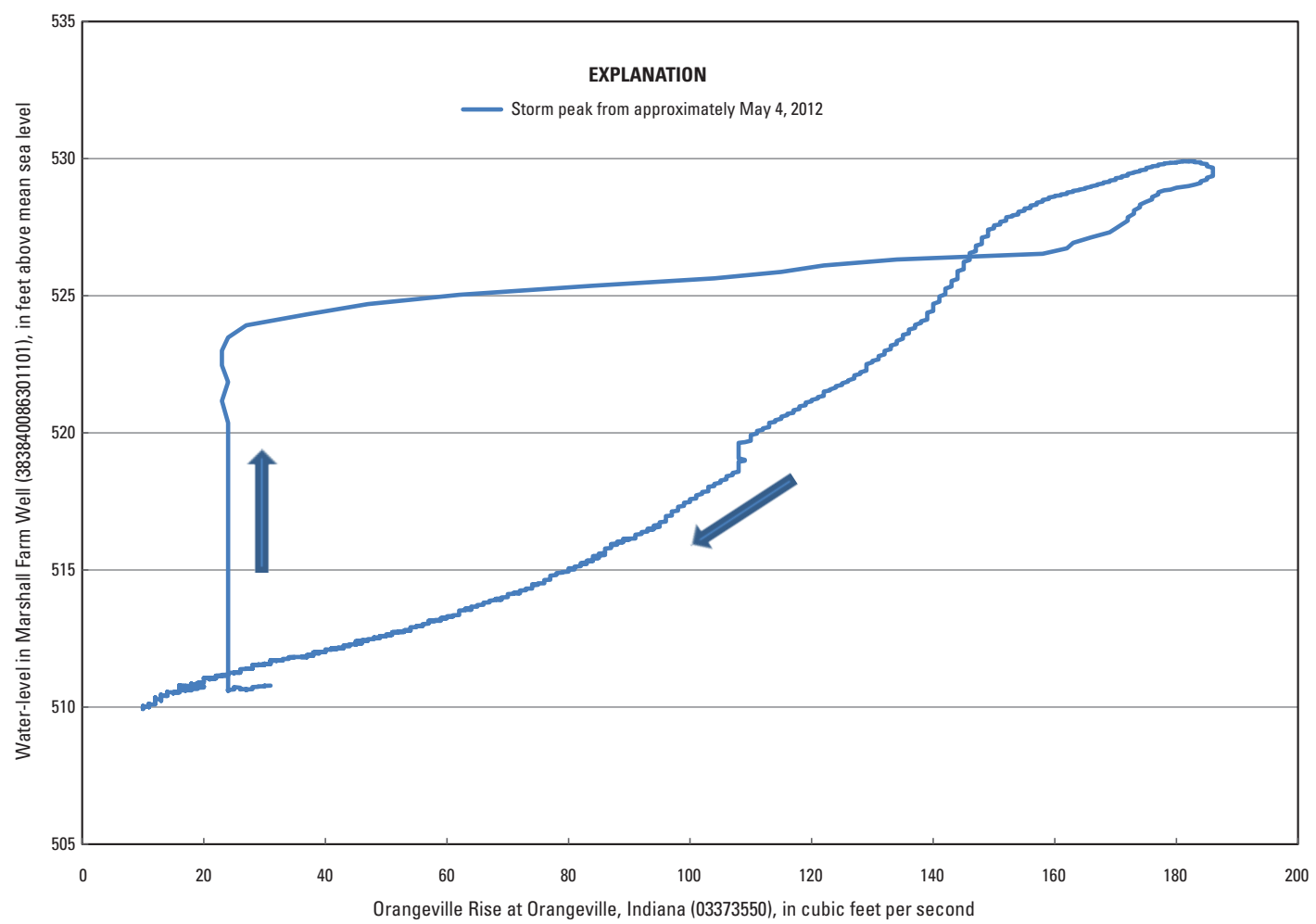

Figure 19. Fifteen-minute unit-value water levels in the Marshall Farm Well, Indiana (383840086301101), versus 15-minute unitvalue streamflow originating from the Orangeville Rise, Indiana (03373550), showing an early clockwise hysteresis followed by a counterclockwise hysteresis that is indicative of an early groundwater influx followed by a more subtle rise that lags slightly behind the surface-water peak. This event started on May 4, 2012.

Table 8. Monthly results from sliding-interval, hydrograph-separation analysis (Sloto and Crouse (1996)) for station 03373550 (Orangeville Rise at Orangeville, Indiana), November 1, 2011 to February 28, 2013.

[ $\mathrm{ft}^{3} / \mathrm{s}$, cubic foot per second]

\begin{tabular}{lcccc}
\hline Month and year & $\begin{array}{c}\text { Mean } \\
\text { total flow } \\
\text { (ft } \mathbf{3} / \mathbf{s})\end{array}$ & $\begin{array}{c}\text { Mean } \\
\text { base flow } \\
\text { (ft } \mathbf{3} / \mathbf{s})\end{array}$ & $\begin{array}{c}\text { Mean } \\
\text { overland flow } \\
\text { (ft } \mathbf{3} / \mathbf{s})\end{array}$ & $\begin{array}{c}\text { Base flow/overland } \\
\text { flow ratio } \\
\text { (percent) }\end{array}$ \\
\hline November 2011 & 66.43 & 40.32 & 26.11 & 60.69 \\
December 2011 & 164.71 & 143.94 & 20.77 & 87.39 \\
January 2012 & 137.81 & 116.19 & 21.61 & 84.32 \\
February 2012 & 82.59 & 74.90 & 7.69 & 90.69 \\
March 2012 & 112.81 & 89.26 & 23.55 & 79.12 \\
April 2012 & 42.40 & 33.87 & 8.53 & 79.87 \\
May 2012 & 43.39 & 25.61 & 17.77 & 59.03 \\
June 2012 & 8.57 & 8.34 & 0.23 & 97.35 \\
July 2012 & 8.40 & 8.27 & 0.13 & 98.46 \\
August 2012 & 8.50 & 8.20 & 0.30 & 96.51 \\
September 2012 & 16.94 & 9.16 & 7.78 & 54.08 \\
October 2012 & 22.26 & 14.29 & 7.97 & 64.20 \\
November 2012 & 11.64 & 10.27 & 1.37 & 88.20 \\
December 2012 & 36.15 & 19.32 & 16.83 & 53.45 \\
January 2013 & 115.29 & 87.32 & 27.97 & 75.74 \\
February 2013 & 117.25 & 103.00 & 14.25 & 87.85 \\
\hline
\end{tabular}




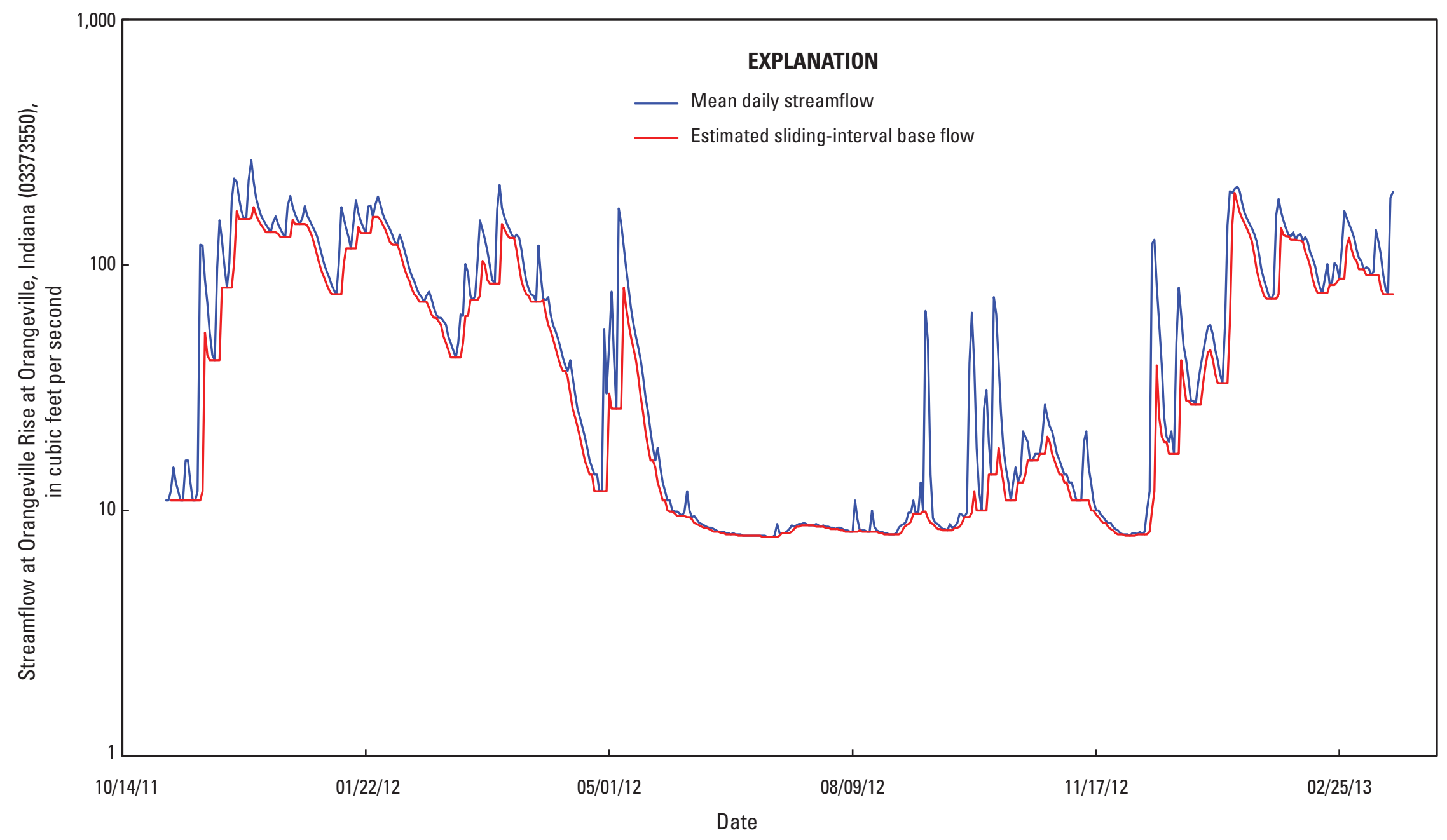

Figure 20. Estimated base flow, following Sloto and Crouse (1996, p. 4), for U.S. Geological Survey streamflow-gaging station 03373550 (Orangeville Rise at Orangeville, Indiana), November 1, 2011-February 28, 2013. 


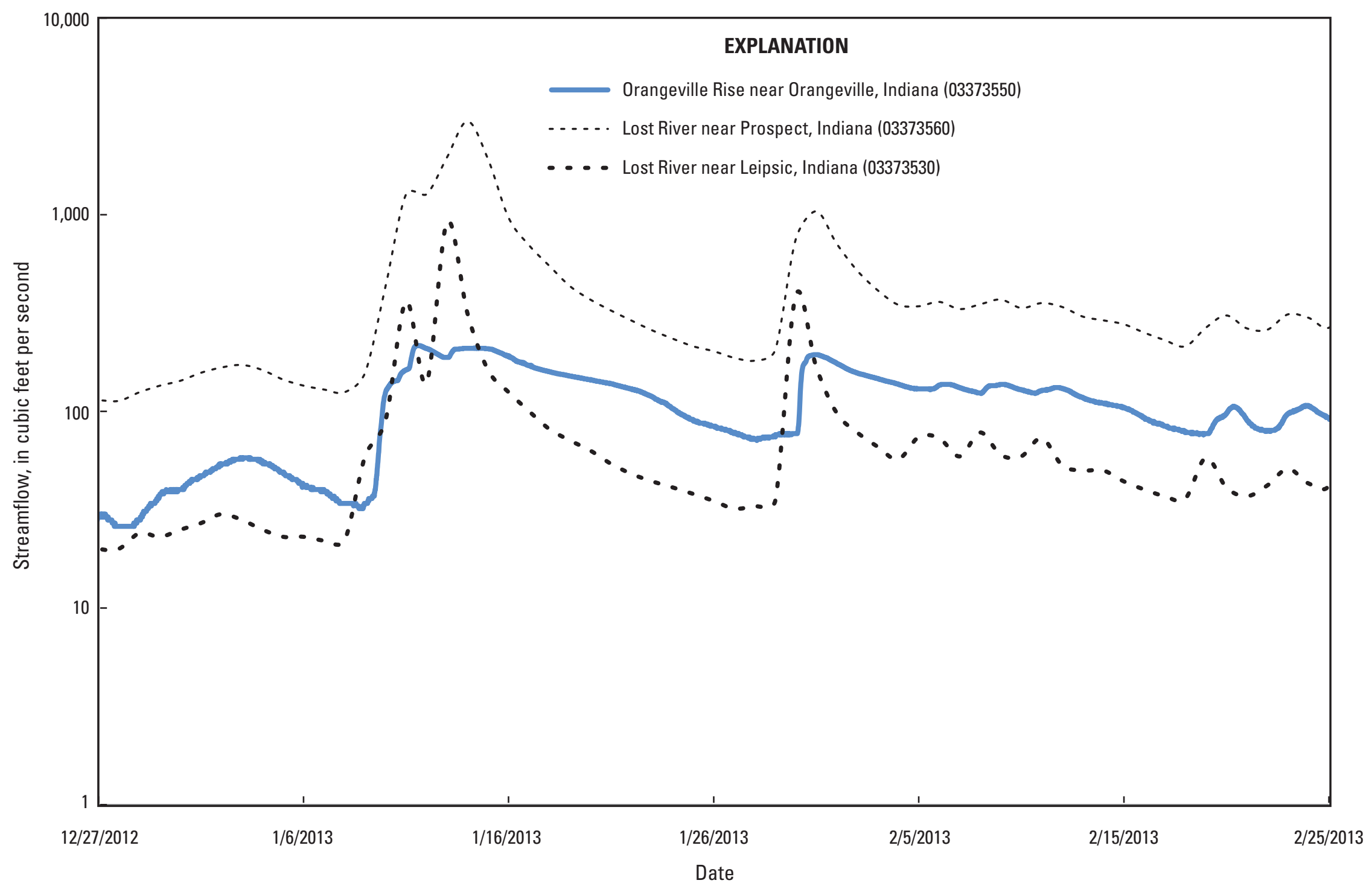

Figure 21. Streamflow at Lost River near Leipsic, Indiana (03373530), Orangeville Rise near Orangeville, Indiana (03373550), and Lost River near Prospect, Indiana (03373560), streamflow-gaging stations showing a potential bounding condition at the Orangeville Rise near approximately 200 cubic feet per second. 


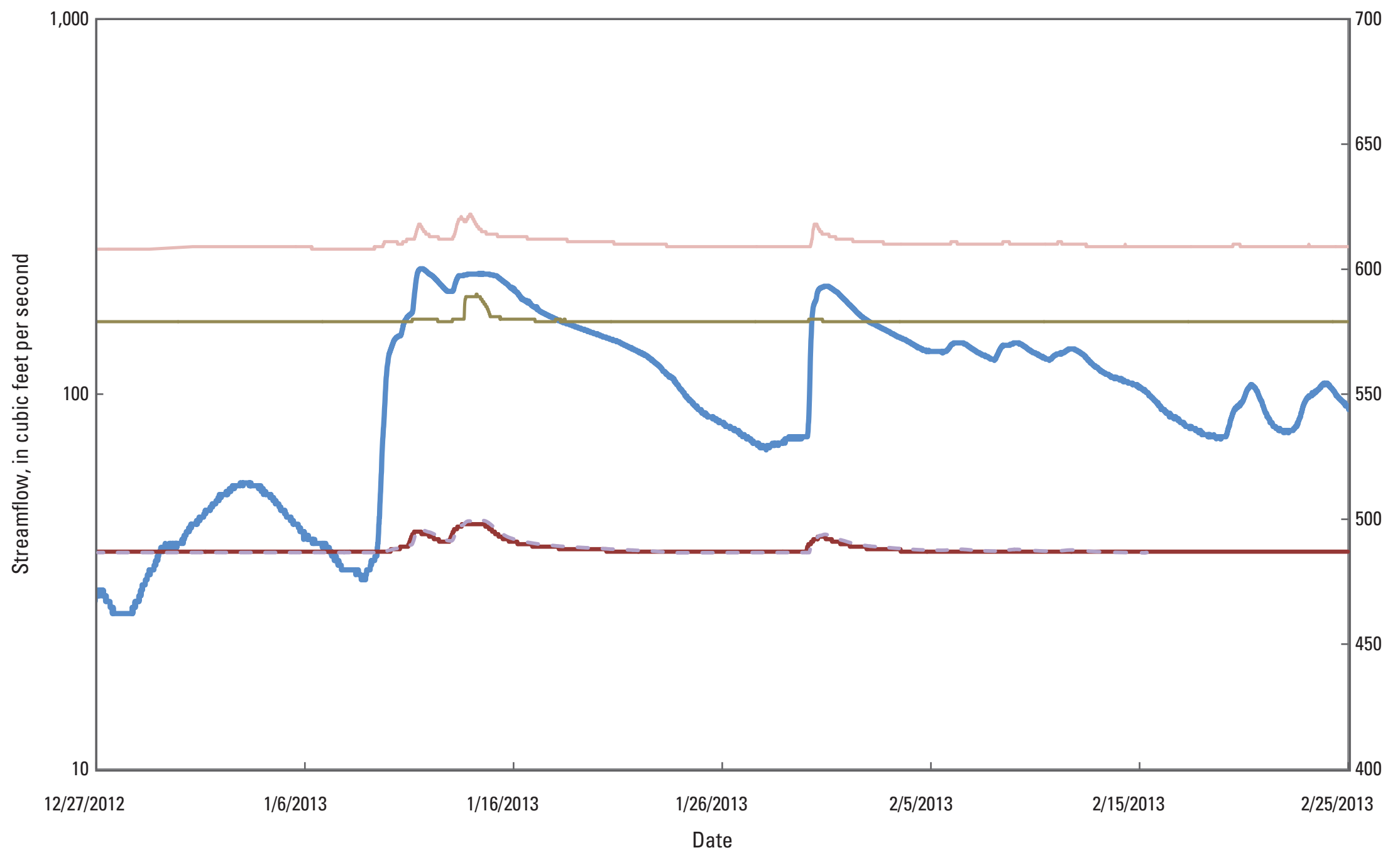

\section{EXPLANATION}

Orangeville Rise near Orangeville, Indiana (03373550) (in cubic feet per second)

_ Lost River at CR100E (383708086262000) (water-surface elevation)

— Lost River at CR500N (383748086293300) (water-surface elevation)

— Dry Branch at CR525W (383748086332200) (water-surface elevation)

- - - Lost River at CR525W (3872608633200) (water-surface elevation)

Figure 22. Streamflow at Orangeville Rise, Indiana (03373550), and water-surface elevation at Lost River at CR100E, CR500N, CR525W, and Dry Branch at CR525W showing activation of flows during periods when flows emerging from the Orangeville Rise are at, or near, approximately 200 cubic feet per second. 
In addition to flooding in the community of Orleans, flooding of the Lost River also is of interest for this study. Flooding of the Lost River downstream from the Orangeville Rise appears to depend on the discharge from the Orangeville Rise and its stormwater overflow springs, the contribution of the true rise of Lost River, and local inputs such as those from Lick Creek. The combined sources of water from the aforementioned locations in both the Orangeville Rise watershed and the larger Lost River watershed contribute to flooding at French Lick and West Baden, Ind.

\section{Limitations of Field-Data Analysis}

Data collected and utilized during this study represent a limited period of observation and are not intended to represent the entire range of conditions that might occur in the upper Lost River study area. Additional data are required to fully describe the range of conditions that could potentially occur, for example, greater than 10 years of climate record are typically needed to fully capture cyclic patterns that may occur over decadal time scales. The intent of this report is to make general observations based on the limited, available data and pre-existing knowledge of the site. These observations are intended to help emergency managers in the region make more-informed decisions. As with any analysis of limited data, additional data and further study will, most certainly, alter the interpretation of these findings and help to better understand this highly complex system.

\section{Summary and Conclusions}

The U.S. Geological Survey (USGS), in cooperation with the U.S. Army Corps of Engineers (USACE) and the Indiana Office of Community and Rural Affairs (OCRA), conducted a study of the upper Lost River watershed in Orange County Indiana, from 2012 to 2013. The Water Availability Tool for Environmental Resources (WATER)-TOPMODEL simulations and field observations were used to gain an improved understanding of the factors affecting flooding in the upper Lost River watershed, Orange County, Ind., and to provide tools that could be used by resource managers to prepare for flood emergencies. The WATER-TOPMODEL application was constructed and run as described in Williamson and others (2009) and Taylor and others (2012). The correlation between observed and simulated hydrographs was qualified by a correlation coefficient of 0.36 and a Nash-Sutcliffe efficiency (Ef) of 0.32 for the Lost River near Leipsic, Ind. (03373530), simulation watershed, and a correlation coefficient of 0.49 and an Ef of 0.28 for the Lost River near Prospect, Ind.
(03373560), simulation watershed. The simulation results were locally improved by applying a parameter estimation software (PEST) tool. Statistics from WATER-TOPMODEL using optimized parameters included a correlation coefficient of 0.58, and an Ef of 0.56 for the Lost River near Leipsic, Ind., simulation watershed and a correlation coefficient of 0.60 , and an Ef of 0.39 for the Lost River near Prospect, Ind., simulation watershed.

Analysis of surface-water and karst groundwater interactions showed that bounding conditions within the watershed can be identified through analytical methods such as hydrograph separation and hysteretic loops. The results show a bounding limit of approximately 200 cubic feet per second at the Orangeville Rise (03373550) and a well-connected conduit system feeding into the rise. Monitoring of the relative volume of water exiting the Orangeville Rise as well as monitoring (or modeling) the water entering the system from critical upstream areas, such as the Flood Creek watershed, may therefore provide much needed management tools and information to assess when the conduit system may reach its capacity and, potentially, cause localized flooding.

Given the complex hydrologic and hydraulic behavior of the Lost River watershed, the U.S. Geological Survey (USGS) WATER-TOPMODEL application developed for the watershed can begin to provide water-resource managers with a planning and mitigation tool to better protect life and property in the region. Although the coupling of the karst and surface-water systems provided by the WATER-TOPMODEL application provides a tool unavailable in the past for planning and mitigation, additional data (especially during actual flooding conditions) will be needed to refine the model in the future. For example, when the Orangeville Rise is exhibiting elevated base-flow conditions, modeled projections of streamflow contributions to the upper part of the watershed (through Flood Creek) begin to gain importance in providing predictive information regarding the potential for flooding within the regional relic stream channels and karst paleovalleys. In effect, when the conduit system draining to the Orangeville Rise is at or near capacity, additional inputs from higher in the watershed potentially could be subject to hydraulic damming and forced to the surface via the many stormwater rises in the region; this excess water could cause localized flooding within the local relic stream channels and karst paleovalleys. Flooding within the Orangeville Rise area, and by the previously noted mechanisms, also could increase the potential for flooding in the downstream perennial reaches of the Lost River as the Orangeville Rise is tied, hydrologically and hydraulically, to the downstream watersheds. If the monitoring network installed for development and calibration of the WATERTOPMODEL application is preserved in its entirety in order to capture future flood events, it is expected that the tool can be substantially improved in the future. 


\section{References Cited}

Band, L.E.; Peterson, D.L.; Running, S.W.; Coughlan, Joseph; Lammers, Richard; Dungan, Jennifer; and Nemani, Ramakrishna, 1991, Forest ecosystem processes at the watershed scale-Basis for distributed simulation: Ecological Modelling, v. 56, p. 171-196.

Bassett, J., 1976, Hydrology and geochemistry of the upper Lost River drainage watershed, Indiana: National Speleological Society Bulletin, v. 38, no. 4, p. 79-87.

Bassett, J.L., 1974, Hydrology and geochemistry of karst terrain, upper Lost River drainage watershed, Indiana: Bloomington, Ind., Indiana University, A.M. thesis, 102 p.

Bassett, J.L., and Ruhe, R.V., 1974, Geomorphology, hydrology, and soils in karst, southern Indiana-Field Conference, April 24-25, 1974: Bloomington, Ind., Indiana University, Water Resources Research Center, 54 p.

Bayless, E.R., Taylor, C.J., and Hopkins, M.S., 1994, Directions of ground-water flow and locations of ground-water divides in the Lost River watershed near Orleans, Indiana: U.S. Geological Survey Water-Resources Investigations Report 94-4195, 25 p., 2 pls.

Beven, K.J., 1986a, Runoff production and flood frequency in catchments of order $n$ - An alternative approach, in Gupta, V.K., Rodriguez-Iturbe, I., and Wood, E.F., eds., Scale problems in hydrology: Dordrecht, The Netherlands, D. Reidel Publishing Company, p. 107-131.

Beven, K.J., 1986b, Hillslope runoff processes and flood frequency characteristics, in Abrahams, A.D., ed., Hillslope processes: St. Leonards, Australia, Allen \& Unwin, p. 187-202.

Beven, K.J., and Kirkby, M.J., 1979, A physically-based variable contributing area model of watershed hydrology: Hydrological Sciences Bulletin, v. 24, no. 1, p. 43-69.

Beven, K.J., Kirkby, M.J., Schofield, N., and Tagg, A.F., 1984, Testing a physically-based flood forecasting model (TOPMODEL) for three U.K. catchments: Journal of Hydrology, v. 69 , no. 1, p. 119-143.

Beven, K.J., and Wood, E.F., 1983, Catchment geomorphology and the dynamics of runoff contributing areas: Journal of Hydrology, v. 65, nos. 1-3, p. 139-158.

Cunningham, W.L., and Schalk, C.W., comps., 2011, Groundwater technical procedures of the U.S. Geological Survey: U.S. Geological Survey Techniques and Methods 1-A1, $151 \mathrm{p}$.
Evans, C., Davies, T.D., and Murdoch, P.S., 1999, Component flow processes at four streams in the Catskill Mountains, New York, analyzed using episodic concentration/discharge relationships: Hydrological Processes, v. 13, no. 4, p. 563575 .

Famiglietti, J.S., 1992, Aggregation and scaling of spatiallyvariable hydrological processes-Local, catchment-scale and macroscale models of water and energy balance: Princeton, N.J., Princeton University, Ph.D. dissertation, 207 p.

Famiglietti, J.S., and Wood, E.F., 1991, Evapotranspiration and runoff from large land areas_-Land surface hydrology for atmospheric general circulation models: Surveys in Geophysics, v. 12, nos. 1-3, p. 179-204.

Freeze, R.A, and Cherry J.A., 1979, Groundwater: Englewood Cliffs, N.J., Prentice-Hall, 604 p.

Gallagher, Mark, and Doherty, John, 2007, Parameter estimation and uncertainty analysis for a watershed model: Environmental Modelling \& Software, v. 22, no. 7, p. 1000 1020 .

Gray, H.H., 2000, Physiographic divisions of Indiana: Indiana Geological Survey Special Report 61, 15 p., 2 figs., 1 pl.

Hasenmueller, N.R., Rexroad, C.B., Powell, R.L., Buehler, M.A., and Bassett, J.L., 2003, Karst geology and hydrology of the Spring Mill Lake and Lost River drainage watersheds in southern Indiana: Indiana Geological Survey Guidebook 15, 29 p., 24 figs., 2 pls.

Homer, C.H., Fry, J.A., and Barnes, C.A., 2012, The National Land Cover Database: U.S. Geological Survey Fact Sheet 2012-3020, 4 p.

Ijjász-Vásquez, E.J., Bras, R.L., and Moglen, G.E., 1992, Sensitivity of a watershed evolution model to the nature of runoff production and to initial conditions: Water Resources Research, v. 28, no. 10, p. 2733-2741.

Jenson, S.K., and Domingue, J.O., 1988, Extracting topographic structure from digital elevation data for geographic information system analysis: Photogrammetric Engineering and Remote Sensing, v. 54, no. 11, p. 1593-1600.

Jordan, P.R., and Combs, L.J., eds., 1996, Summary of floods in the United States during 1990 and 1991: U.S. Geological Survey Water-Supply Paper 2474, 254 p.

Kennen, J.G., Kauffman, L.J., Ayers, M.A., Wolock, D.M., and Colarullo, S.J., 2008, Use of an integrated flow model to estimate ecologically relevant hydrologic characteristics at stream biomonitoring sites: Ecological Modelling, v. 211, nos. 1-2, p. 57-76. 
Kirkby, M.J., 1986, A runoff simulation model based on hillslope topography, in Gupta, V.K., Rodriguez-Iturbe, I., and Wood, E.F., eds., Scale problems in hydrology—Runoff generation and response: Dordrecht, The Netherlands, D. Reidel Publishing Company, p. 39-56.

Malott, C.A., 1952, The swallow-holes of Lost River, Orange County, Indiana: Proceedings of the Indiana Academy of Science, v. 61, p. 187-231.

McCuen, R.H., Knight, Zachary, and Cutter, A.G., 2006, Evaluation of the Nash-Sutcliffe efficiency index: Journal of Hydrologic Engineering, v. 11, no. 6, p. 597-602.

Murdock, S.H., and Powell, R.L., 1968, Subterranean drainage of Lost River, Orange County, Indiana: Proceedings of the Indiana Academy of Science, v. 77, p. 250-255.

Nash, J.E., and Sutcliffe, J.V., 1970, River flow forecasting through conceptual models part $1-$ A discussion of principles: Journal of Hydrology, v. 10, no. 3, p. 282-290.

National Oceanic and Atmospheric Administration, 2013, Climate.gov-Science \& information for a climate-smart nation, accessed December 2013, at http://www.climate. gov/\#dataServices.

Purdue University, 2013, Iclimate.org-Indiana State Climate Office, accessed September 2013, at https://climate.agry. purdue.edu/climate/index.asp.

Quinn, P.F., Beven, K.J., and Lamb, R., 1997, The wetness index-How to calculate it and how to use it within the TOPMODEL framework, in Beven, K.J., ed., Distributed hydrological modelling - Applications of the TOPMODEL concept: Chichester, England, Wiley, p. 31-52.

Rantz, S.E., and others, 1982a, Measurement and computation of streamflow-Volume 1-Measurement of stage and discharge: U.S. Geological Survey Water-Supply Paper 2175, $284 \mathrm{p}$.

Rantz, S.E., and others, $1982 \mathrm{~b}$, Measurement and computation of streamflow-Volume 2-Computation of discharge: U.S. Geological Survey Water-Supply Paper 2175, 631 p.

Ries, K.G., III, Guthrie, J.G., Rea, A.H., Steeves, P.A., and Stewart, D.W., 2008, StreamStats-A water resources web application: U.S. Geological Survey Fact Sheet 2008-3067, $6 \mathrm{p}$.

Ruhe, R.V., 1975, Geohydrology of karst terrain, Lost River Watershed southern Indiana: Bloomington, Ind., Indiana University, Water Resources Research Center, Report of Investigations No. 7, 91 p.

Sauer, V.B., and Turnipseed, D.P., 2010, Stage measurement at gaging stations: U.S. Geological Survey Techniques and Methods book 3, chap. A7, 45 p. (Also available at http:// pubs.usgs.gov/tm/tm3-a7/.)
Schneider, A.F., 1966, Physiography, in Natural features of Indiana: Proceedings of the Indiana Academy of Science, Sesquicentennial Volume, p. 40-56.

Shaver, R.H., Ault, C.H., Burger, A.M., Carr, D.D., Droste, J.B., Eggert, D.L., Gray, H.H., Harper, D., Hasenmueller, N.R., Hasenmueller, W.A., Horowitz, A.S., Hutchison, H.C., Keith, B.D., Keller, S.J., Patton, J.B., Rexroad, C.B., and Wier, C.E., 1986, Compendium of Paleozoic rock-unit stratigraphy in Indiana-A revision: Indiana Department of Natural Resources, Geological Survey Bulletin 59, 203 p.

Sivapalan, Murugesu, Beven, K.J., and Wood, E.F., 1987, On hydrologic similarity - 2, A scaled model of storm runoff production: Water Resources Research, v. 23, no. 12, p. 2266-2278.

Sloto, R.A., and Crouse, M.Y., 1996, HYSEP-A computer program for streamflow hydrograph separation and analysis: U.S. Geological Survey Water-Resources Investigations Report 96-4040, 46 p.

Taylor, C.J., and Nelson Jr., H.L., 2008, A compilation of provisional karst geospatial data for the Interior Low Plateaus physiographic region, central United States: U.S. Geological Survey Data Series 339, 26 p.

Taylor, C.J., Williamson, T.N., Newson, J.K., Ulery, R.L., Nelson, H.L., Jr., and Cinotto, P.J., 2012, Phase II modification of the Water Availability Tool for Environmental Resources (WATER) for Kentucky - The sinkhole-drainage process, point-and-click watershed delineation, and results of karst test-watershed simulations: U.S. Geological Survey Scientific Investigations Report 2012-5071, 19 p. (plus appendixes).

U.S. Department of Agriculture-Natural Resources Conservation Service, 1986, Urban hydrology for small watersheds (2d ed.): Conservation Engineering Division, Technical Release 55, 210-VI-TR-55, $94 \mathrm{p}$.

U.S. Department of Agriculture-Natural Resources Conservation Service, 2007, Soil Survey Geographic (SSURGO) database for Kentucky (by county), accessed December 2013, at http://websoilsurvey.sc.egov.usda.gov/.

U.S. Geological Survey, 2011a, National Hydrography Dataset (NHD+), accessed September 2011, at http://nhd.usgs.gov/.

U.S. Geological Survey, 2011b, Digital elevation models (DEMs): Earth Resources Observation and Science (EROS) Center, accessed September 2011, at http://eros.usgs. gov/\#F ind_Data/Products_and_Data_Available/DE M s.

U.S. Geological Survey, 2011c, Multi-Resolution Land Characteristics Consortium (MRLC) National Land Cover Database (NLCD2006), accessed November 2013, at http:// www.mrlc.gov/nlcd2006.php. 
U.S. Geological Survey, 2011d, Geo Data Portal, accessed November 2013, at http://cida.usgs.gov/gdp/.

Vitvar, T., Burns, D.A., Lawrence, G.B., McDonnel, J.J., and Wolock, D.M., 2002, Estimation of baseflow residence times in watersheds from the runoff hydrograph recession-Method and application in the Neversink watershed, Catskill Mountains, New York: Hydrological Processes, v. 16 , no. 9 , p. $1871-1877$.

Williamson, T.N., Odom, K.R., Newson, J.K., Downs, A.C., Nelson Jr., H.L., Cinotto, P.J., and Ayers, M.A., 2009, The Water Availability Tool for Environmental Resources (WATER) - A water-budget modeling approach for managing water-supply resources in Kentucky—Phase I-Data processing, model development, and application to nonkarst areas: U.S. Geological Survey Scientific Investigations Report 2009-5248, 34 p.

Wolock, D.M., 1988, Topographic and soil hydraulic control of flow paths and soil contact time-Effects on surface water acidification: Charlottesville, Va., University of Virginia, Ph.D. dissertation, $188 \mathrm{p}$.

Wolock, D.M., and Hornberger, G.M., 1991, Hydrological effects of changes in atmospheric carbon dioxide levels: Journal of Forecasting, v. 10, p. 105-116.
Wolock, D.M., Hornberger, G.M., Beven, K.J., and Campbell, W.G., 1989, The relationship of catchment topography and soil hydraulic characteristics to lake alkalinity in the northeastern United States: Water Resources Research, v. 25, no. 5 , p. 829-837.

Wolock, D.M., Hornberger, G.M., and Musgrove, T.J., 1990, Topographic effects on flow path and surface water chemistry of the Llyn Brianne catchments in Wales: Journal of Hydrology, v. 115, nos. 1-4, p. 243-259.

Wolock, D.M., and McCabe, G.J., Jr., 1999, Explaining spatial variability in mean annual runoff in the conterminous United States: Climate Research, v. 11, no. 2, p. 149-159.

Wood, E.F., Sivapalan, Murugesu, and Beven, K.J., 1990, Similarity and scale in catchment storm response: Reviews of Geophysics, v. 28, no. 1, p. 1-18.

Wood, E.F., Sivapalan, Murugesu, Beven, K.J., and Band, L.E., 1988, Effects of spatial variability and scale with implications to hydrologic modeling: Journal of Hydrology, v. 102 , nos. $1-4$, p. $29-47$. 

Publishing support provided by the U.S. Geological Survey Science Publishing Network,

Columbus Publishing Service Center

For more information concerning the research in this report, contact the

Director, Kentucky Water Science Center

U.S. Geological Survey

9818 Bluegrass Parkway

Louisville, KY 40299-1906

http://ky.water.usgs.gov/ 
